\title{
Lise Öğrencilerinin Rol Model Tercihlerine İlişsin Bir Çalışma
}

\author{
A Study on the Role Model Preferences of High School \\ Students
}

\begin{abstract}
Mehmet Tahir KARABOĞA*
Öz: Bu araştırma, lise öğrencilerinin farklı kurumlardan ve alanlardan hangi rol modelleri ne ölçüde tercih ettiğini tespit etmeyi amaçlamaktadır. Bu araştırmanın verileri, 2018-2019 öğretim yılı güz dönemi sonunda Mersin ilinde merkeze bağlı Şevket Pozcu Anadolu Lisesi, İçel Anadolu Lisesi, Mersin Ticaret ve Sanayi Odası Anadolu Lisesi, Mahmut Arslan Anadolu Lisesi, Dumlupınar Anadolu İmam Hatip Lisesi, Fatma Aliye Mesleki ve Teknik Anadolu Lisesi ve Mersin Mesleki ve Teknik Anadolu Lisesinde kayıtlı 700 lise öğrencisine uygulanan "Lise Öğrencilerinin Rol Model Tercihleri” adlı anket doğrultusunda toplanmıştır. Araştırmaya katılan lise öğrencilerinin rol model olarak kimleri tercih ettikleri hakkındaki görüşleri araştırma alt problemleri izlenerek frekans ve yüzdelik betimleyici istatistiksel teknikleri ile incelenmiştir. Araştırmanın bulguları lise öğrencilerinin medya ünlülerini yüksek bir oranda rol model olarak tercih etiklerini göstermektedir. Lise öğrencilerinin aile bireylerini, tarihi karakterleri, profesyonel meslek grubundaki kişileri, bilim insanlarını, öğretmenleri, edebi karakter ve yazarları rol model olarak tercih etme oranlarının düşük düzeyde olduğu tespit edilmiştir. Lise öğrencilerinin politikacıları, dini figürleri, arkadaş çevresindeki kişileri rol model olarak tercih etme oranlarının ise oldukça düşük olduğu görülmüştür. Lise öğrencilerinin medya alanında en çok sırasıyla dizi ve sinema oyuncularını, müzisyenleri ve sporcuları rol model olarak tercih ettikleri tespit edilmiștir.

Anahtar Kelimeler: Lise öğrencilerinin rol modelleri, rol model ve medya ünlüleri, rol model ve aile, rol model ve eğitim, sosyal öğrenme
\end{abstract}

\begin{abstract}
This research aims to determine to what extent high school students choose which role models from different institutions and areas. The data of this research were gathered from 700 high school students registered in Şevket Pozcu Anatolian High School, İçel Anatolian High School, Mersin Chamber of Commerce and Industry Anatolian High School, Mahmut Arslan Anatolian High School, Dumlupınar Anatolian Imam Hatip High School, Fatma Aliye Vocational and Technical Anatolian High School and Mersin Vocational and Technical High School through High School Students' Role Model Preferences Questionnaire. The opinions of the secondary school students who participated in the research about who they preferred as a role model were examined with frequency and percentage descriptive statistical techniques by following the research questions. The findings of the study show that high school students preferred media celebrities as a role model at a high rate. It was determined that the ratio of preferring family members, historical characters, people in professional occupation groups, scientists, teachers, literary characters, and authors as role models was low. It has been observed that the rate of secondary school students' preference of politicians, religious figures, and friends as role models is quite low. It has been determined that high school students prefer primarily TV series and cinema players, musicians and athletes among media celebrities as role models.
\end{abstract}

Keywords: Role models of high school students, role models and media celebrities, role models and family, role models and education, social learning

\section{Giriş}

Toplumsal kurumlar, belirli hedefler doğrultusunda aktarmak istediği kültürü, bilgiyi, değerleri belirli rol modeller üzerinden gerçekleştirmeye çalışırlar. Günümüzde lise aşamasında öğrenim gören öğrencilerin rol modellerine önemli ölçüde aile, okul, arkadaş çevresi kadar medya da

*Dr. Öğr. Üyesi, Mersin Üniversitesi, Eğitim Fakültesi, Mersin-Türkiye, ORCİD. 0000-0003-07957991: e-posta: tahirkaraboga@mersin.edu.tr 
kaynaklık etmektedir. Ailede daha çok anne ve baba rol model olurken, okulda öğretmen ve ders kitaplarında sunulan belirli kişilikler rol modeldir. Medyanın rol modelleri ise dizi ve film oyuncular1, müzisyenler, sunucular, mankenler gibi medya ünlüleri olabilmektedir.

Rol modeller bireylerin karar verme davranışı, karakter oluşumu ve gelişimi üzerinde doğrudan ya da dolaylı etkileri bulunan bir özellik taşırlar. Aile kurumu tarafından çocuktan beklenen davranış özellikleri; kişinin önce kendisine sonra ülkesine yararlı olması, iletişim becerisi, yaratıcıllğı ve üreticiliğinin gelişmiş olması, toplumsal norm ve değerleri öğrenmiş bir birey olması yönündedir. Okul kurumu ise, hem öğretmen ve yönetici hem de kitaplarda sunduğu rol modeller ile öğrencilerin belirli bilgi, beceri ve tutumlar ile donanmış olmalarını, bir meslek sahibi olmalarını, öğrencilerde olumlu karakter özelliklerinin oluşması ve gelişiminin teşvik edilmesi, sosyalleşmelerinin sağlanması yönündedir. Okulun önemli rol modelleri arasında olan öğretmenler, ülkenin kalkınmasında, zenginleşmesinde, bireylerin sosyalleşmesinde, yaşama hazırlanmasında, toplumsal değerlerin aktarılmasında, bireyin sahip olduğu düșünce sistemi ve dünyayı görme șeklinin belirlenmesinde önemli rol oynar. Okul kurumu öğretmen gibi okul kitaplarında tarihi karakterler, politikacı, şair, yazar, ressam, filozof, psikolog, ekonomist, sosyolog gibi mesleklerden kişileri de rol model olarak sunar. Bir ülkenin ekonomik olarak kalkınması ve zenginleşmesi, kültürel olarak gelişmesi açısından profesyonel mesleklerdeki rol modellerin okul ortamlarında sunulması önemlidir.

Medya kurumunun rol model olarak sunduğu medya ünlüleri ise, endüstriyel sistem tarafindan ekonomik ve kültürel amaçlar doğrultusunda üretilmekte, tasarlanmakta ve pazarlanmaktadır. $\mathrm{Bu}$ anlamda amaç, yapı ve hedefler açısından medyanın sunduğu rol modeller, okul ve aile kurumlarının sunduğu rol modellerden önemli ölçüde farklılaşmaktadır. Medyanın sunduğu modellerin ise endüstriyel sistem tarafından ekonomik çıkar çerçevesinde yapılandırılması, kurgusal ve gerçek dışı olması, hayali ve sanal olması, eğlence ve tüketim kültürü ile yoğrulması, bilimsellik taşımaması, şiddet ve cinsiyetçilik ile iç içe olması açısından önemli ölçüde farklılık gösterdiği düşünülmektedir.

Medya kuruluşları belirli ekonomik ve kültürel hedefler çerçevesinde genç kesimleri popüler kişiler üzerinden, onların sosyal olayları, kişileri, hayatı nasıl algılayacakları noktasında eğitmekte, onların önemli bir bilgi ve sosyalleşme kaynağını oluşturmaktadır. Medyada sunulan rol modellere yönelik önemli bir eleştiri konusu, bu modellerin çoğunlukla şiddet eğilimli, şiddet uygulayan karakterler olması ve bunu izleyen ve tüketen bireyler tarafından bu şiddetin benimsenmesi ve uygulanmasına neden olduğu yönündedir. Yapılan pek çok araştırma, medya araçlarında, dizi ve sinema filmlerinde karakterlerin şiddet kullanmasının şiddet eğilimli bireyler yetiştirilmesine zemin hazırladığını ve şiddet içerikli medya ürünlerini tüketenlerin şiddet uygulama eğilimlerinin artı̆ğ görüşünü desteklemektedir.

Medya ünlüleri aracılığıyla bireylerin tüketim alışkanlığ 1 ve ürünlere sahip olma isteği değişebilmekte, markalara yönelik algıları değiştirebilmekte, bireyin tüketim beklentileri etkilenmekte, ürünlere yönelik bağımlılığ içeriklerinin önemli bir bölümü, bireylerin tüketim konusunda yönlendirilerek, onların sürekli ve daha çok satın almaları ve iyi bir tüketici olmaları konusuna odaklanmaktadır.

$\mathrm{Bu}$ araştırma, lise öğrencilerinin rol model olarak kimleri tercih ettiklerini tespit etmeyi amaçlamaktadır. $\mathrm{Bu}$ çalışma, lise öğrencilerinin tercih ettikleri rol modelleri arasında medya ünlüleri, öğretmen, aile bireyi, tarihi karakter, dini figür, bilim insanı, politikacı, şair, yazar, ressam, filozof, psikolog, ekonomist, sosyolog gibi farklı alanlardan kişilerin ne oranda yer aldığını tespit etmeye çalışmaktadır. Aynı zamanda lise öğrencilerinin tercih ettikleri rol modellerin özellikleri hakkındaki görüşleri ve rol modellerini tercih etme nedenlerinin neler olduğunu ortaya çıkarmayı amaçlamaktadır.

\section{Sosyal öğrenme kuramı}

Sosyal öğrenme kuramı bireylerin gözlem yaparak öğrenmesine vurgu yapan bir kuramdır. Bu kurama göre, birey gelişiminin ilk dönemlerinde başkalarının davranışlarını önce gözlemler, daha sonra bu davranışları taklit etmeye başlar. Bireyin gelişiminin ileriki safhalarında ise taklit davranışı yerini model alma davranışına bırakır. Bu kuramın önde gelen ismi Albert 
Bandura'dır. Bandura'ya (1986, s. 47) göre, kişiler kendi tecrübeleri ve başkalarının bilgi ve tecrübelerinden yararlanarak onları taklit ederek öğrenme işlemini gerçekleştirirler. Birçok insan, başka kişilerin davranışını gözlem yaparak öğrenir. Diğer kişiler gözlenirken davranışın nasıl yapıldığ1 ve davranışla ilgili kurallar kodlanır ve öğrenilir. Bu öğrenmeler daha sonraki süreçlerde davranışlara rehberlik ederler. Modelleme olarak tanımlanan bu öğrenme süreci, psikolojide farklı kavramlarla karşılanmış olmakla birlikte,değerleri, düşünceleri ve davranış kalıplarını iletmenin en güçlü yollarından biri olarak kabul edilmiştir.

Bandura'ya (1977) göre insanlar toplumdan yalıtılmış bir biçimde yaşamazlar. Sosyal bir varlık olarak ödüllendirildikleri, dikkate alınmadıkları veya cezalandırıldıkları durumlarda başkalarının davranışlarını gözlemlerler. $\mathrm{Bu}$ nedenle, gözlemlenen sonuçlardan veya kendi doğrudan tecrübelerinden faydalanabilirler. Bandura (1977) gözlemsel öğrenmeyi, mekanik bir kopyalama işleminden ziyade bireyin aktif bir şekilde yargılayıcı ve yapıcı olarak işlemlerden geçirdiği bir öğrenme olarak tanımlar. Gözleyerek öğrenme, sadece bir kişinin diğer kişilerin etkinliklerini basit olarak taklit etmesi değil, çevredeki olayları bilişsel olarak işlemesiyle kazanılan bilgidir. Bandura gözlem yoluyla öğrenme ile taklit yoluyla öğrenmenin birbirinin yerine kullanılabilecek iki kavram olmadığını açıklamaktadır. Gözlem yoluyla öğrenme, taklidi içerebilir de içermeyebilir (Senemoğlu, 2007, s. 218). Sosyal öğrenme teorisine göre, önce çevrede çok çeşitli uyaranlardan modelleme uyaranları seçilir ve zihinsel olarak depolanır. Önceden gözlemlenen bir davranışı yerine getirmek için bir firsat ortaya çıktığında, gözlem yoluyla elde edilen bilgiler, bireyin motor yetenekleri dâhilinde olması koşuluyla, belli bir hareketi yönlendirmek için kullanılır (Manz ve Sims, 1981, s. 107).

Bandura, gözlemle öğrenme kapasitesinin, insanların bilgi ve becerilerini başkaları tarafından sergilenen bilgilere dayanarak gelişim sağladığını vurgular."Sosyal öğrenme, başkalarının gerçek performanslarını ve onlar için ne gibi sonuçların ortaya çıktığını gözlemleyerek desteklenir. Bununla birlikte, modellemenin özel bir üstünlüğü, geniş bir uygulanabilirlik bilgisini aynı anda çok sayıda insana sembolik modeller aracılı̆̆ıyla iletebilmesidir. Gözlemciler, kelime ve görüntülerde tasvir edilen davranış kalıplarına dayanarak, yakın çevrelerinin sınırlarını aşabilirler" (Bandura, 1986, s. 47).

Bandura'ya göre "gözlemci, modelden beş konuda öğrenebilir. Birey, başkalarını gözlemleyerek yeni bilişsel ve psikomotor beceriler öğrenebilir. Bireyin modeli gözlemesi sonucu, önceki öğrenmiş olduğu yasaklar güçlenir veya zayıflar. Gözlemci yeni değerler ve inançlar kazanabilir. Gözlemci, modelden çevrenin ve eşyaların nasıl kullanılacağını da öğrenir. Gözlemci, modelin duygularını açıklama biçimini gözleyerek, kendi de benzer biçimde duygularını açıklayabilir" (Akt. Senemoğlu, 2007, ss. 229-230). "Model alma yoluyla gözlenen kişideki değerlerin içselleştirilmesi yoluyla bireylerin kişilik yapılarında önemli değişiklikler ortaya çıkar. Değerler benlik kavramının özünü oluşturarak eylem ve düşünceleri etkiler. Bu yolla insanların davranışlarına yön veren ölçütler oluşturmalarına neden olur" (Sarı, 2005, s. 77).

Sosyal öğrenme teorisine göre tanımlanma olarak da ele alınabilen modelleme, yeni tepkilerin kazanıldığı ve mevcut davranış repertuarlarının bir dereceye kadar, davranışları, değerleri olan çok çeşitli gerçek veya sembolik modellerle hem doğrudan hem de açık deneyimlerin bir fonksiyonu olarak değiştirildiği sürekli bir süreçtir. Bir aile davranış için genel reçeteler sunabilse de, ebeveyn modelleri muhtemelen sosyal gelişimin farklı aşamalarında gereken ayrıntılı becerilerin ve davranış biçimlerinin birincil kaynakları olarak hizmet edemez. Karmaşık kültürel davranış kalıpları, büyük ölçüde, sosyal sistemler düzeyinde iletilir ve düzenlenir (Bandura, 1969, s. 255).

Öte yandan, öykünmüş davranış kaynaklarının belirlenmesi sorunu, çocukların öğretmenler, yakın çevrede bulunan diğer yetişkinler, akran arkadaşları ve çoğunlukla televizyon ve filmler aracılığıyla sunulan bir dizi prestijli modelin de dâhil olduğu çoklu modellere maruz kalması nedeniyle karmaşıktır. Bu nedenle, çocukların farklı gelişim dönemlerinde karakteristik olarak sergilenen farklı modellerine yanıt olarak yalnızca ebeveynlere güvenmeleri son derece şüphelidir (Bandura 1969, s. 215).Bandura'ya (1969, s. 248) göre çocuklar büyüdükçe, çeşitli nedenlerden dolayı yaşıtlarına ve aile dışı modellere daha 
fazla ağırlık vermelidirler. İlk olarak, hızlı sosyal ve teknolojik değișim koșulları altında, daha erken bir dönemde uygulanabilir olan birçok ebeveyn çıkarları, tutumları ve rol davranışları, genç neslin üyeleri için çok az işlevsel değere sahip olabilir.

Bandura (1969) ihmal edilen bir diğer etkili sosyal öğrenme kaynağı olarak televizyonda ve diğer görsel-işitsel gösterimlerde sunulan bol ve çeşitli sembolik modellemelere vurgu yapmakta ve film gösterimlerinin sağladığı modellerin çocukların davranışlarını şekillendirmede gerçek hayattaki emsalleri kadar etkili olabileceğine değinmektedir. Bandura rol modelin davranışlar üzerindeki etkileri açısından prestij, güç, yeterlilik, sosyo-ekonomik durum ve uzmanlık gibi model niteliklerinin önemli değişkenler olarak sosyal psikolojide ele alındığını belirtmektedir. Bandura (1969) bir rol modelin, ayırt edici özelliklerinin bu niteliklere sahip olmayan modellerden çok daha fazla, hem çocuklar hem de yetişkinler açısından, taklit davranış üzerinde etkili olduğunu ifade etmektedir. Modelin yaş, cinsiyet, sosyal güç ve etnik statü gibi özellikleri başkalarını etkileyebildiğini söylemektedir. Bir modelin gözlemciyi etkileyip etkilemediğini belirleyen bir bașka faktör de, modelin başarılı veya başarısızlıkla karşılanıp karşılanmadığıdır. Gözlemcinin bazı özellikleri de modelleme sürecinde önemli bir rol oynayabilir. Genel olarak, çeşitli araştırmacılar tarafindan, bireysel özelliklerin, öğrenme sürecini etkileyeceği belirtilmiştir. Bireylerin belirli bir zamanda sergilediği nitelikler, öz sayg1 ve beklentiler, kişisel korku ve yaratıcı eğilimler gibi özelliklerin öğrenmeyi etkilemesi muhtemeldir (Manz ve Sims, 1981).

\section{Rol model kavramı}

Rol modeller; bireylerin hayranı oldukları ve onları taklit ettikleri kişilerdir. Rol modellerin, bireylerin karar verme süreçleri ve karakter gelişimi üzerinde doğrudan ya da dolaylı etkileri bulunmaktadır. Günümüzde genelde çocuk, ergen ve gençleri oluşturan kesimlerin rol modellerine çoğunlukla aile, okul, arkadaş çevresi ve medya dediğimiz kitle iletişim araçları kaynaklık etmektedir. Ailede daha çok anne ve baba rol model olurken, okulda öğretmen ve ders kitaplarında sunulan belirli kişilikler rol modeldir. Rol modeller çocukluk döneminden, ergenlik ve gençlik dönemine geçişle birlikte değişir. Model alınan kişilerin arasında popüler medya kahramanları ön plana çıkmaya başlar. Öğrenciler ergenlik ve gençlik döneminde televizyonda gördükleri ünlü kahramanlar gibi yaşamaya, onlar gibi giyinmeye, konuşma, hayran oldukları ünlü popüler kahramanları özelliklerini taklit etmeye başlarlar. Bu rol model karakterler çizgi film karamanı, dizi oyuncuları, şarkıcılar, futbolcular, mankenler vb. kişiler olabilmektedir. Bu örnekler, öğrenci kesimleri tarafından bir idol olarak kabul edilebilmekte, öğrencilerin kimlikleri, karakterleri ve davranış özellikleri üzerinde etkili olabilmektedir.

Ergenler genellikle kendi öz imajlarını, yaşam tarzlarını ve tüketim modellerini oluştururken çeşitli dış menfaatlerden etkilenirler (Martin ve Bush, 2000). Bir ergen için rol modeli, ergenin kararlarını veya davranışlarını etkileyebilecek, doğrudan veya dolaylı olarak, potansiyel olarak temas edebileceği herhangi biri olabilir (Bandura, 1977) Buradan hareketle Martin ve Bush (2000) ebeveynler, kardeşler, akranlar, öğretmenler, eğlendiriciler ve sporcular dâhil olmak üzere çeşitli bireylerin rol model olarak görülmesine olanak tanıyabileceğini belirtmektedir. Rol modeller doğrudan etkileşim içinde bulunulan aile, arkadaş, akraba olabildiği gibi, dolaylı etkileşimde bulunulan sporcular, televizyon ve film yıldızları ya da diğer ünlü kişiler de olabilmektedir.

Polat'a göre de, geçmiş zamanlarda çocuğun kahraman olarak gördüğü modeller çoğunlukla yakınındaki insanlar olurken, günümüzde ise dünyanın herhangi bir yerindeki bir futbolcu veya şarkıcı da kahraman olabilmektedir. Birey kendi yaşamı içinde bulunan olumlu değerleri olan ya da davranışlar gösteren kişileri içselleştirebilmek için kahraman olarak kabul edebilirler (Polat, 2012, s. 7).

Rol model olarak kabul edilen bir kişinin gösterdiği, sergilediği davranış örnekleri kişi tarafından model alınır ve taklit edilir. Kişilerin düşünsel, duyuşsal ve davranışsal özellikleri, modelin gözlemlenmesinden sonra değişmektedir. Rol model kişiler, tüm hareketleri davranışları, tutumları gözleyenler tarafından yakından takip edilmekte, rol modeller bazen sahip olduğu özellikler açısından normal insanlardan farklılık gösterebilmektedir. 
Bir kişinin davranışları, meslek alanındaki başarısı, toplum tarafından çok tanınan biri olması, takdir görmesi, ya da özel yaşamındaki başarıları diğer insanlar tarafından rol modeli olarak benimsenmesinde etkili olabilmektedir. Bunun yanında kişinin dikkat çekici özelliklere sahip olması, yaş, cinsiyet, saygınlık, statü ve güç, model alınmasında belirleyici olabilmektedir (Bandura, 1969).

Özellikle gelişim çağlarında yetişkinliğe adım atan bireyler kendisini örnek aldığ kişi ile özdeşleştirebilmektedir. Model alınan kişi, anne-baba, öğretmen olabildiği gibi medyadaki popüler bir kişi, bir bilim insanı, bir dini lider, bir hayali çizgi film kahramanı olabilmektedir. Model alma süresinde ergen kişinin sadece hareketleri ve karakteri değişmekle kalmamakta çoğu zaman giyim kuşam, saç şekli, yaşam tarzına da yansıyarak kendini gösterebilmektedir. Demirbaş ve Yağbasan'a (2005) göre, kişiler her gördüğü davranışı öğrenmez veya model almazlar. Gözlemleyen için, davranışların dolaylı etkisi, sadece sonuçlardan değil, onların karakteristik yapısından da kaynaklanır. Model ile gözlemleyenin karakter benzerlikleri veya özellikleri davranışın model alınma oranını artırabilir. Öcal, Polat ve Arı'ya (2011, s. 1327) göre ise, rol modeller, gözlem, öykünme yoluyla benzerlik gösteren, bireyi geliştirmek için motive eden ve onların tutumlarını, davranışlarını, amaçlarını ya da onların statü pozisyonlarının cazibeleri açısından bazı benzerlikleri algıladıkları, insanları daha çekici bulan bireyleri belirtir. Kelman (1961), kişinin yaşadığı problemlerin çözümünde faydalı gördüğü, kendine yakın hissettiği, hoşuna gittiği, birtakım fikir, düşünce ve davranışları benimsediğini ifade eder. Model olarak benimsenen kişinin düşünce ya da davranışları gözleyen tarafından içselleştirilebilmekte ve güvenilir bulunabilmektedir. Fakat burada önemli olan nokta model olarak benimsenen varlığın güvenirliğidir. Kişi etkilendiği kişi ya da grubun bütün ya da bazı davranışlarını model olarak alabilmektedir. Kişi kendisini diğerleri ile karşılaştırarak model aldığ 1 kişi ne söylerse onu söyleme, ne yaparsa onu yapmaya ve neye inanırsa ona inanma eğilimi gösterebilmektedir. Ailede anne ve baba, okulda öğretmeni model alma, bilgi, beceri ve davranış öğretmek, açısından bilgiye motive etmek ve onların değerlerini geliştirmeye yardım etmek açısından önemlidir.

\section{Rol model olarak aile}

Aile, tüm toplumsal kurumlar içinde en temel ve en eski kurumlardan biridir. Aile aynı zamanda çocuğun dünyaya geldiği andan itibaren içinde bulunduğu ilk eğitim ortamıdır. İnsan, çevresinin ürünü olduğundan ailenin bireyin kişiliğinin oluşmasında, toplumsallaşmasında ve yetkin bir kişi olmasındaki rolü büyüktür. Çocuk, aile ortamında anne ve babasını model alarak öğrenir.

Aile, çocukların davranışlarını pekiştiren ve çocuklarına inançları ileten, tutum ve davranışlarının şekillenmesine yardımcı olan birincil kaynaktır. Her çocuk, bir aile içinde dünyaya gelerek çevresi ile etkileşime girer. Bu etkileşim sonucunda çevresinde konuşulan dili, toplumun uyduğu görgü kurallarını, toplumsal norm ve değerleri öğrenir. Aile çocukların ilk öğretmeni ve rol modelidir. Çocuklar genellikle ailelerinin ne söylediklerinden ziyade ne yaptıklarından daha çok etkilenmektedir. Anne babalarının nasıl davrandıklarını görerek kendi davranışlarını buna göre şekillendirmektedir.

Özel ve Zelyurt'a (2016, s. 11) göre gelişen ve değișen dünyaya uyum sağlayan bireylerin yetişmesinde ailenin büyük bir rolü vardır. Bireylerin ilk eğitimlerini ailede aldıkları düşünüldüğünde aile eğitiminin önemi kendini göstermektedir. Çocuğun gelişimi, çevresiyle olan etkileşimi ile doğru orantılıdır. Aileler, çocukların içinde bulundukları durumda onların nasıl desteklenmesi gerektiğini bilirlerse buna en uygun olan tutumu sergileyebilirler. Annebabası tarafından desteklenen, başarıları takdir edilen, yeri geldiğinde yaptığı yanlışı fark ettirilen çocuklar, sağlıklı bir kişilik gelişimi gösterirler.

Ailede anne ve babanın sosyo-ekonomik durumu, kültürel seviyeleri, arkadaşlık ve okul çevresi çocuğun kişilik oluşumunda önemli rol oynar. Çocuk büyüdükçe, sosyal varlık olarak, aile dışına çıkarak toplumsal ilişkilerini geliştirmeye başlar, arkadaş grubuyla ve diğer sosyal ortamlar ile etkileşim davranış ve tutumlarına yansır. 


\section{Rol model olarak öğretmen}

Model sunma bilgi, beceri ve davranış öğretmek, öğrencileri öğrenmeye motive etmek için etkili bir yol olarak düşünülmektedir. Öğrencilerde olumlu karakter oluşumu ve gelişimini teşvik etmek, sosyalleşmesini sağlamak, sosyal kimlik kazandırmak amacıyla başta öğretmen olmak üzere ders kitaplarında da belirli kahramanlar rol modeller olarak sunulmaktadır. Öğrenciler, öğretmenlerinin giyimini, konuşmalarını, hareketlerini, tavırlarını, tutumlarını, sorun çözme yöntemlerini, değerlerini kendilerine örnek alabilmektedirler.

Okul kurumunun en önemli eğitici aktörü olan öğretmenler ülkenin kalkınmasında, bireylerin sosyalleşmesinde, yaşama hazırlanmasında, toplumsal değerlerin aktarılmasında, bireyin sahip olduğu düşünce sistemi ve dünyayı görme şeklinin belirlenmesinde önemli rol oynar. Öğretmen, okul kurumlarında öğrencilere birtakım bilgi ve becerilerin kazandırılmasında, öğretilmesinde rol oynayan önemli bir figürdür. Öğrencilerin, okulda öğretmenlerden aldıkları eğitim ve bilgi sonucunda davranış, düşünüş ve duygularında birtakım değişiklikler meydana gelir. Kılıç, Kaya, Yıldırım ve Genç'e (2004) göre, okullarda öğretmenler öğrencilere örnek rol model kahramanı olma görevini üstlenmiştir. Öğrenciler, öğretmenlerinin davranışlarını, konuşmalarını, hareketlerini, giyimini, tutumlarını, olaylara ve insanlara yaklaşımını örnek alabilmektedir."Öğrenciler, öğretmenlerinin demokratik ya da katı tutumlarını, sorun çözme yöntemlerini, değerlerini kendilerine örnek alma eğilimindelerdir" (Kılıç ve diğerleri, 2004). Öcal ve diğerleri (2011) formal eğitim sürecinin okullarda, bir program çerçevesinde ve nitelikli öğreticiler tarafından gerçekleştirilirken ders kitaplarında veya kitap dışı eğitim-öğretim sürecinde öğrencilere birçok konunun bazı karakterler ve modeller yolu ile öğretildiğini belirtmektedirler. Yazarlar bu noktada iyi modellerin bireyin kariyer yaşantısını ve başarısını olumlu etkileyebileceğini, olumsuz rol-modellerin ise bireyin kariyer basamaklarını tırmanmasında olumsuz etkiler yapabileceğini ifade etmektedir.

Öğretmen, bir toplumun geleceği olan bireyleri yetiştiren ve çocukları hayata hazırlayan kişidir. Bu nedenle toplumun şekillenmesinde öğretmene oldukça önemli görevler düşmektedir. $\mathrm{Bu}$ durum da öğretmenin mesleki yeterliliklerinin yanı sıra, birçok niteliğe sahip olmasını gerekli kılmaktadır. Öğretmenlerin iyi yetişmiş olmalarıyla birlikte öğrencilere iyi birer model olmaları öğrencilerin davranışlarını da etkileyeceğinden, öğretmenlerin öğrenciler tarafından rol model olarak görüldüklerine dair farkındalıklarının açı̆̆a çıkarılması son derece önemlidir (Demir ve Köse, 2016, s. 40). Sorunlu öğrenci davranışlarının çözümünde yönetici ve öğretmenlerin rol model davranışlarının önemine değinen Yener (2011), öğretmenlerin alanlarında uzman olması gerektiği gibi davranışlarına da önem vermesi gerektiğini, eğitimci ve öğrenci etkileşimi ne kadar etkili olursa öğrencinin gözlemlediği davranışları gösterme becerisinin de o kadar arttığını ifade etmektedir.

Öğrencilerin iyi yetiştirilmesi öğretmenler tarafından verilen eğitimin kalitesine, eğitimin kalitesi de öğretmenin iyi yetiştirilmiş olmasına dolaysıyla eğitimin kalitesi ve niteliği büyük ölçüde öğretmen niteliğine bağlı olmaktadır (Seferoğlu, 2001; Şişman, 2006). Öğrenciler, öğretmenlerinin giyim şekillerini, konuşmalarını, demokratik ya da katı tutumlarını, sorun çözme yöntemlerini, değerlerini kendilerine örnek alma eğilimindedirler. Öğretmenlerin, öğrencilerinin demokratik değerlerin kazanılmasında önemli bir yeri vardır. Çünkü öğrencilerdeki değişim sadece onlara söylenenler üzerinden değil, uygulamalar ve somutlaşan davranışlar üzerinden gerçekleşir (Kılıç, Kaya, Yıldırım ve Genç, 2004, s. 6). Çocuk ve genç bireylerin hayatı ve hayata bakışı öğrenmesinde, tutum ve davranış geliştirmelerinde bu bireylere örnek ve rol model olan kişilerin bireyin eğitiminde kaçınılmaz olarak önemli bir yeri vardır. Görevi itibariyle eğitim dünyasının temel taşlarından olan öğretmenlerin, öğrencilere olumlu ya da olumsuz örnek olabilecekleri önemli bir gerçektir. Öğretmenler kültürü temsil eden kişiler olarak ögrencilerin sosyalleşmesinde ve kültür aktarımında çok önemli bir yere sahiptirler (Demir ve Köse, 2014, s. 8).

\section{Rol model olarak medya ünlüleri}

Medya, günümüzde okul ve aile gibi eğitim kurumlarının işlevine benzer bir rolü yerine getirir. Medyanın genç nesilleri eğiten, aile ve okullarla rekabet edebilen önemli bir eğitim kaynağı 
haline geldiği görülmektedir. Gündelik toplumsal yaşamın vazgeçilmez bir eğlence ve eğitim kaynağı haline gelen medya içerikleri, başta çocuklar ve gençler olmak üzere milyonlarca bireyin bilgi, duygu, düşünce, inanç, tutum ve davranışlarını etkileyen bir güce de sahiptir. Günlük yaşamda başta genç kesim olmak üzere pek çok kesimin dünyaya ilişkin bilgileri, tutum ve davranışları artık medya aracılığıyla kazandığını söylemek mümkündür.

Medya ünlüleri, medya tarafından popüler yapılan, tanıtılan, sunulan dizi oyuncuları, sinema aktörleri, çizgi film kahramanları, müzisyenler, spikerler, komedyenler, modacılar, mankenler, futbolcular vb. kişileri kapsamaktadır. Rol modeller farklı program türleri içinde (dizi filmler, çizgi filmler, müzik programları, yarışma programları, haberler, magazin programları, sinema filmleri, futbol programları vb.) sunulmaktadır.

Medyanın rol modelleri ve karakterleri okul ve aile kurumlarının sunduğu rol modellerden birçok açıdan farklılaşmaktadır. Aile tarafindan çocuğa sunulan ve ondan beklenen davranış özellikleri; bireyin kendisine ve topluma yararlı iletişim becerisi yüksek, yaratıcı, üretici kişilik özellikleri olan, toplumsal norm ve değerleri öğrenmiş bir birey olması yönündedir. Okul kurumu ise, hem öğretmen hem de kitaplarda sunduğu rol model kahramanlar ile öğrencilerin bilgi, beceri ve davranış öğretilmesi, öğrencilerde olumlu karakter özellikleri oluşumu ve gelişimini teşvik edilmesi, sosyalleşmesinin sağlanması, sosyal kimliğin kazandırılması yönündedir. Medyanın sunduğu rol modeller, okul ve aile kurumlarının sunduğu rol modellerden gerçeklik ve hayali olması açısından da farklılaşabilmektedir. Aile ve okul çocuklara yaşayan veya yaşamış gerçek kişileri rol model olarak sunarken; medya ise çoğunlukla kurgusal ve hayali, gerçek dışı, olağanüstü özelliklerle donatılmış karakterleri rol model olarak sunmaktadır.

Medyanın topluma ve özellikle çocuklar ve gençlere sunduğu rol modellere ilişkin bazı noktalarda önemli eleştiriler yöneltmek mümkündür. Bunlardan biri bireylerin tüketime teşvik edilmesi, tüketici yaşam tarzının sunulması, satın alma davranışlarının öğretilmesidir. Diğer bir eleştiri noktası ise, sunulan rol modellerin şiddet eğilimli ve şiddet uygulayan karakterler olması ve bunu izleyen bireyler tarafından bu şiddetin benimsenmesi ve uygulanması riskidir.

Medya ünlülerinin endüstriyel bir sistem tarafindan ekonomik ve kültürel amaçlar doğrultusunda üretilmesi, tasarlanması ve pazarlanması bu kişilerin ortak özelliklerini oluşturmaktadır. Günümüz küresel kapitalizm koşullarında televizyon programları ile üretilen rol modellerin tanıtılması, ünlü hale getirilmesi, pazarlamada kullanılması durumunun çokuluslu şirketler tarafından gerçekleştirildiğini söylemek mümkündür. Televizyon programları ile güvenilir, inanılır ve beğenilir kahramanlar, kişiler (popüler şahsiyetler, aktörler, müzisyenler, haber spikerleri, sunucular, dizi ve film starları gibi) üreterek bunların ürün ve hizmetlerin satışında kullanılması oldukça yaygın bir durumdur.

Kıyan'a (2016) göre küresel ölçekte ele alındığında kültür endüstrisine birkaç büyük şirketin yön verdiği görülmektedir. "Uluslararası film sektöründe dağıtım, piyasanın \%80'inden fazlasını elinde tutan yedi büyük şirket tarafından gerçekleştirilmektedir. Bunlar Warner Bros, Universal, 20th Century, Walt Disney, Paramount, Lionsgate, Weinstein Company, Sony/Columbia. Benzer bir durum müzik endüstrisinde de geçerlidir. BU şirketler sırasıyla şunlardır: Sony Music, EMI Group, Warner Music Group ve Universal Music Group. Müzik piyasasının \%70'i bu şirketlerin elinde bulunmaktadır. Dev medya şirketleri film, müzik, televizyon, yazılı basın, web içerikleri vb. alanlara hâkim konumdadır.

Endüstriyel sistem tarafından üretilen televizyon programları ile yaşam bulan rol modeller, programların akışında yiyip içmekte, giyinmekte, satın almakta, araba, cep telefonu kullanmakta, mobilya takımları kullanmakta, kolye, yüzük, gözlük gibi takılar giymekte, kafeye, eğlence ve tatil yerlerine gitmektedir. Bu karakterlerin kişisel özellikleri ve onların ürünlerle olan ilişkileri, izleyicilerin bu ürünlere yönelik yaklaşımlarını, algılarını ve satın alma eğilimlerini etkileyebilmektedir. Bu karakterlerin ne giydiği, nerede yemek yediği, ne satın aldığı, hangi teknolojik ürünleri kullandığı, ne tür aksesuarlar kullandığı izleyicilerin tüketim ürünlerini satın alma davranışını yönlendirebilmektedir (Karaboğa, 2016).

Bocock'a (1997) göre televizyon programlarında popüler karakterler etrafında tüketim malları ve yaşam tarzları seyredilir. Mobilyalar, evlerin dekorasyonu, otomobiller, giysiler, 
yeme içme alışkanlıkları, karakterlerin saç stili, giysileri ve kozmetikler izleyicilerin gözünde arzulanan yaşam tarzları olarak algılanan imajlar yaratır. Bocock, izleyicilerin televizyon programlarındaki karakterleri etrafında gördükleri mallardan etkilendiklerini ve bu malların benzerlerine sahip olmak istediklerini belirtir.

Medya, popüler ünlüler üzerinden ürünlere anlamlar yükleyerek bu ürünlerin kullanımı ve sahip olunması halinde bireylerin popüler kişiler gibi kabul ve beğeni göreceğini; statü, prestij ve saygınlık göreceği mesajlarını verir. Televizyon programlarının insanların zengin ve lüks bir hayat yaşama arzusunu kışkırttığını, pahalı ve lüks tüketim ürünlerine ve yaşam biçimine özendirdiğini bunu da ürettiği ünlü kişiler üzerinden gerçekleştirdiğini söylemek mümkündür. Programlar haz, mutluluk, zenginlik ürünlerle özdeşleştirilmekte, daha iyi yaşam koşulu hayalleri ürünlere sahip olmakla ifade edilmektedir. Mutluluk ve özgürlüğün anlamı, son model lüks arabalarla eğlence yerlerine gitmek ve buralarda para harcamakla, pahalı giysilerle boy göstermekle, pahalı cep telefonları, markalı moda ürünleri ve lüks evlere sahip olmakla özdeşleştirilmektedir.

Kellner'e göre (2010) medya, günlük hayat için tüketim idolleri ve şahısları yansıtan örnekler bularak, yeni ürünler ve öykünecek modeller satmaktadır. Medya taklit ve rekabet içinde moda ikonları oluşturmakta, idoller ve örnek kişiler bularak şöhret kültürünü teşvik etmektedir. Kellner'e göre, "eğlence sanayisinin yıldızları; taklit ve gipta edilen moda ikonları ve modelleri haline gelmiştir. Gösteri kültüründe tarz ve görünüm gündelik hayatta giderek önem kazanmış, kimliğin ve kendini ifade etmenin yolu haline gelmiştir. Medya kültürünün gösterileri, insanlara nasıl görünmeleri ve nasıl davranmaları gerektiğini göstermekte ve bildirmektedir" (Kellner, 2010, ss. 25-32).

Medyada sunulan ünlü kişiler olumlu hayali özellikler ile kurgulandığı için sıradan insanlara göre daha çekici gelebilmektedir. Medya tarafindan yaratılan ve üretilen kahramanların, cesaretli, zeki, güzel yakışıklı ve güçlü olmak gibi olağanüstü özelliklerle donatılması ve eğlenceli olması itibariyle dikkat ve ilgi çekebilmektedir. Medya kahramanları özellikle genç kitlelere hitap edecek şekilde tasarlanmakta ve kurgulanmaktadır. Medya; olayları, yaşamı, öğretmen ve diğer eğitim aktörlerinden daha eğlenceli ve çekici bir tarzda sunabilmektedir. Birçok genç insan her gün saatlerce medya içeriklerini tüketmekte ve kahramanlar üzerinden bir eğitim sürecine maruz kalmaktadır. Mesaj sağanağı altında izleyiciler, kahramanlar ile özdeşleşebilmekte, onlara özenebilmekte, güvenebilmekte, onları rol model olarak benimseyerek onlar gibi olmak, onları gibi giyinmek, konuşmak onlar gibi yaşamak ve kabul görmeyi arzu etmektedir.

Medya ve özellikle televizyon bağlamında modelleme, televizyon programlarında, özellikle dizi ve filmlerde başrol oyuncusu gibi önemli rolleri oynayan kişilik ve karakterlerin izleyiciler tarafindan örnek alınması, o modele uygun davranış ve tutumların sergilenmesi ve modele benzeme çabası olarak tanımlanabilir. Chiou, Huang ve Chuang, bireylerin erken yaşlardan itibaren belirli davranışlarda bulunurken diğer insanların davranışlarını gözlemleyerek, model alarak kendine yön vermeye çalıştıklarını belirtir. Chiou, Huang ve Chuang (2005) modern toplumlardaki ünlü hayranlığının, kitle iletişim araçlarının ve iletişimin doğrudan bir ürünü olduğunu belirtmekte çocuklar ve ergenlerin pop şarkıcıları, sporcular vb. ünlü kişilere yoğun bir ilgi beslediklerini ifade etmektedirler. Erjem ve Çağlayandereli (2006), çocukların ve gençlerin televizyon programlarında özellikle dizi ve filmlerde başrol oyuncusu gibi karakterlerin izleyiciler tarafindan model alındığını, bu karakterlere uygun davranış ve tutumlar sergilediklerini, modele benzeme çabası içinde olduklarını ifade etmektedirler. Erjem ve Çağlayandereli’ye (2006, s. 17) göre, Gençler televizyon dizilerindeki kahramanları modellemeleri; davranış, düşünce ve biçim olarak bu kahramanlara benzemeye çalışmaları dikkat çekmektedir. Özellikle 'popstar' türü yarışma ve eğlence programları, aksiyon filmleri, dizi filmler, gençlerin ilgiyle izledikleri program türleridir. Bu programların sosyalleşme ve kişilik gelişimi sürecinin kritik döneminde bulunan gençleri birçok açıdan (tutum ve değerler edinme, davranış örüntüleri kazanma, rol modellerini gözlemleme, taklit etme gibi) etkilediği ileri sürülebilir. Yurdakul ve Üstün (2009), teknolojik alanda yaşanan gelişmelerle birlikte, modanın etkisi, medya ve modayı sürükleyen şarkıcı, sporcu gibi ünlü kişilerin çocuk-ergenlerin 
davranışları üzerinde özellikle giysi seçimleri üzerinde ailelerinden daha baskın hale geldiğini belirtmektedirler.

Kula Demir (2007, s. 252), televizyon program içeriklerinin yerine getirdiği bu işlevler bakımından ailelerin önüne geçtiğini belirtmektedir. Çünkü bu içerikler, ergen ve gençlere birçok konuda yol göstermekte, rehberlik edip onları bilgilendirmekte ve kültürel değerleri aktarmaktadır. Kula Demir'e göre, gençler, televizyonda gördükleri rol modellerine bakarak, toplum içinde nasıl davranmaları gerektiğine karar vermektedirler. Televizyon metinlerinde yer alan semboller ve imajlar, gençler tarafindan kimliklerini tanımlamak amaciyla kullanılmaktadır. Özellikle televizyon dizileri sürekli takip edilme ve alışkanlık yaratma özellikleri göz önüne alındığında, yarattıkları temsiller ve önerdikleri rol modelleriyle, gençler için davranış, kılık-kıyafet ve yaşam tarzı kodları oluşturmaktadır.

Modern toplumlarda kitle iletişim araçları yoluyla tanınmış, ünlü kişilere duyulan hayranlık hızla yayılmaktadır. Ünlü kişiler, toplumun belirli bir kesimi arasında, belirli bir derece ün kazanmış kişilerdir. Onların ünleri ve başarıları başkalarına ilham olabilmektedir (Run, Butt ve Nee, 2010, s. 72). Türkmen (2014), çocukların erken yaşlardan itibaren kendilerine rol model olarak gördükleri kişilerden etkilendiklerini; bu rol modellerin onların tüketime yönelik tutum ve davranışların, markalara yönelik algılarının şekillendirilmesinde rol oynadığını belirtmektedir. Türkmen'e göre, "çocuklar kendilerine rol model olarak daha çok arkadaş grubundan ya da ünlü kişiler arasından birisini seçmektedirler. Çocukların ünlü kişilerden kendilerine rol model seçmelerinin nedeni, ünlülerin dış görünümlerini beğenmeleri, bu kişilerin fan kulüplerine üye olup kendilerini bu gruba ait hissetmek istemelerinden kaynaklanmaktadır" (s.115). Model alınan kişiler genelde ergen bireyin kendi başına çözümleyemediği sorulara cevaplar veriyor olabilirler. Onları rol model yapan en önemli özellik geniş kitleler tarafından onaylanıyor olmalarıdır. Onaylanma duygusu ise ergenlikte güveni ve yeterlilik hissini uyandıran en önemli faktörlerin başındadır. Bundan dolayı onaylanan rol model gibi davranmak, onun gibi giyinmek, onun gibi konuşmak, kullandığı aksesuarları edinmek ergen için büyük önem taşımaktadır (Hürriyet, 2015).

Türkmen Barutçu ve Sarıkaya da (2016) çocuklar, ünlü kişilere hayran olduğunu ve bu kişilerin kullandıkları ürünleri satın almaya özen gösterdiklerini, onlar gibi giyinmeye, saç modellerini uyguladıklarını hatta hayranı oldukları kişilerin özelliklerine benzer özellikleri kendilerinde taşıyabildiklerini belirtmektedir. Türkmen Barutçu ve Sarıkaya çocukların ünlü kişilere hayranlık duymalarının ardında kitle iletişim araçlarının yer aldığını, özellikle de pop şarkıcıları, sporcular, sinema oyuncuları, dizi film oyuncuları gibi ünlü kişilerden etkilenerek özellikle alışveriş davranışlarında bu durumun gözlemlendiğini belirtmektedir.

Çocukların ilk gelişim süreçlerinden itibaren ergenlik ve gençlik dönemlerine kadar onlara yönelik program türünün başında çizgi filmler gelmektedir. Çocukluk dönemi boyunca çizgi film programları ile ileride ergenlik ve gençlik dönemlerinde benimsenecek rol modellerin alt yapısı hazırlanmaktadır. Çizgi filmlerdeki rol modellerin özellikleri (sanal olması, tüketici karakter taşıması ve şiddet eğilimli olması) ile dizi ve sinema filmlerindeki rol modellerin özellikleri arasında benzerlik görmek mümkündür.

Çizgi film program formatları çocukların dünyasına uygun bir şekilde tasarlanmakta, onların ilgi ihtiyaç ve dikkatlerini çekecek unsurlarla donatılmaktadır. Çocuk uzun bir dönem bu programların kurgulanmış hayali kahramanlarının özelliklerini model alarak eğitilirler. Oruç, Tecim ve Özyürek (2011, s. 305), çocukların televizyonda çizgi filmler aracilığıyla, model alma süreçleri ve beraberinde yaşanan davranış değişikliklerine dikkat çekmektedirler. Onlara göre, henüz hayal ile gerçeği ayırt edemeyen büyük oranda gördüklerinin etkisiyle bir dünya kuran çocuğunun, hem benlik oluşumu hem kişilik gelişimi hem de kültürleme gibi bireysel gelişim süreçlerinde çizgi filmler önemli rol oynamaktadır. "Günde yaklaşık dört saat televizyon karşısında kalan çocuğun kültürel etkileşim konusunda çizgi filmlerdeki davranış kalıplarını, düşünce tarzlarını, model olabilecek kişilerin genel özelliklerini benimsemesi kaçınılmazdır”. Çocuğu etkileyen dış etkenler içerisinde özellikle televizyon yaygın ve egemen konumunu korumakta, politikadan en basit gündelik davranışlara kadar bütün alanlarda belirleyici olmaktadır (Tekarslan, Kılınç, Şencan ve Baysal, 2000, s. 175). Televizyonun ve çizgi filmlerin 
en önemli rolü, çocuklara davranış kalıpları sunmalarıdır. "İnsanın bir davranışı öğrenebilmesi için o davranışın başkaları tarafından nasıl yapıldığının görülmesi gerekmektedir” (Aydın, Akbağ, Tuzcuoğlu, Yaycı ve Ağır, 2005, s. 241).

Çocukluk gelişim evresinden sonra ergenlik ve gençlik evresiyle birlikte televizyon program içeriklerinin bu yaş gruplarına göre değiştiğini görürüz. Özellikle müzik programlarında şarkıcıların, türkücülerin, dizi filmlerde ana karakterlerin, yarışma eğlence programlarında sunucuların, maç programlarında futbolcuların, magazin programlarında mankenlerin bir model olarak bu yaş grubunun ilgileri doğrultusunda ön plana çıktığı görülür.

Medyanın özellikle çocuklar ve gençler başta olmak üzere topluma sunduğu rol modellere ilişkin eleştiri noktalarından biri de şiddet konusudur. Sunulan rol modeller, şiddet uygulayan karakterler olabilmekte bunu izleyen tüketen bireyler ise bu şiddeti benimsenebilmekte ve uygulayabilmektedir.

Yıldı (2007), televizyondan takip edilen programlardaki karakterlerin, çocukların modelleri haline geldiğini, onların davranışlarına, yaşam tarzlarına yansıdığını belirtmektedir. Yıldız'a göre, 16 yaşına kadar bir çocuğun televizyonda 13 bin şiddet eylemine tanık olduğunu, izlenen şiddet eylemlerinin çocuğun ruhsal gerginliği arttırdığını, dürtüsel ve duygusal kontrolü zayıflattığını (s. 123). Aydın, şiddet davranışını televizyon ile kabul edilebilir olduğunu gören çocuklarda yatkınlık oluşturduğunu, bu tip çocukların gelecekte zamanla şiddet içeren görüntüleri izlemeyi tercih ettiklerini belirtmektedir. Aydın'a göre, saldırganca filmler seyredip saldırganlık tepkilerinde artma görülen çocukların, olumlu sosyal ilişkilerinde bir azalma olduğu belirlenmiştir (2005, s. 146). Ertürk ve Gül (2006), televizyon izleyen çocuklarda, fiziksel saldırganlığın artması, şiddete başvurma, şiddete karşı duyarsız olma, okuma zevkinde azalma, ders çalışmaya karşı isteksizlik, dikkatini yoğunlaştıramama, kendini ifade edememe, kendini izlediği kahramanların yerine koyarak gerçeklerden uzaklaşma, hayal gücü ve yaratıcılığın kısıtlanması, sosyal ilişkilerin zayıflaması, gibi olumsuz etkiler saptamıştır. Ünver (2002) de çocukların çizgi film karakterleri ile özdeşim kurduğuna dikkat çekerek, çizgi filmlerde şiddetin yeniden üretiminin çocuklar için zararlı olduğunu vurgulamaktadır. Çocuklar zihinsel süreçlerindeki özelliklerden dolayı izlediklerini yetişkinler gibi algılayamamakta ve yetişkinlerden farklı etkilenmektedir.

\section{Yöntem}

$\mathrm{Bu}$ araştırma, lise öğrencilerinin rol model olarak kimleri tercih ettiğini tespit etmeyi amaçlamaktadır. Araştırma, betimleyici nitelikte bir araştırma olup veriler lise öğrencilerinden anket tekniği ile toplanmıştır. Araştırmanın alt soruları ise şu şekilde belirlenmiştir.

1. Lise ögrencileri rol model olarak kimleri tercih etmektedir?

2. Lise öğrencileri medya ünlüleri rol model tercihlerini hangi alanlardan yapmaktadır?

3. Lise öğrencilerinin rol model tercihi sınıf düzeyine göre değişmekte midir?

4. Lise öğrencilerinin rol model tercihi gelire göre değişmekte midir?

5. Lise öğrencilerinin rol model tercihi cinsiyete göre değişmekte midir?

6. Lise öğrencilerinin rol model tercihi devam ettikleri okullara göre değişmekte midir?

7. Lise öğrencilerinin örnek aldıkları rol modellerin özellikleri hakkında görüşleri nelerdir?

8. Lise öğrencilerin rol modellerini tercih etme nedenlerine ilişkin görüşleri nelerdir?

\section{Çalışma grubu}

Bu araştırmanın çalışma grubu, 2018-2019 öğretim yılında Mersin ilinde merkeze bağlı Şevket Pozcu Anadolu lisesi (1048 öğrenci), İçel Anadolu lisesi (995 öğrenci), Mersin Ticaret ve Sanayi Odası Anadolu Lisesi (891 öğrenci), Mahmut Arslan Anadolu Lisesi (1202 öğrenci), Dumlupınar Anadolu İmam Hatip Lisesi (944 öğrenci), Fatma Aliye Mesleki ve Teknik Anadolu Lisesi (745 öğrenci), Mersin Mesleki ve Teknik Anadolu Lisesi (1513 öğrenci) 7 Liseye kayıtlı 7330 orta öğretim öğrencisi arasından belirlenmiştir. Bu okullar belirlenirken ortaöğretime geçiş başarı durumu ve okul türü özelliklerinin çalışma grubuna yansıtılması 
amaçlanmıştır. Çalışma grubunda yer alan 700 öğrenciye ait özellikler aşağıdaki tabloda belirtilmiştir

Tablo 1.

Araştırmaya Katılan Öğrencilerin Okul, Sınıf, Cinsiyet, Yaş, Gelir ve Aile Kişi Sayısı

Gruplarına İlişkin Frekans ve Yüzde Dağılımları

\begin{tabular}{|c|c|c|}
\hline \multirow[t]{2}{*}{ Okullar } & \multicolumn{2}{|c|}{ Toplam } \\
\hline & $\mathrm{f}$ & $\%$ \\
\hline Şevket Pozcu Anadolu Lisesi & 100 & 14.3 \\
\hline İçel Anadolu Lisesi & 100 & 14.3 \\
\hline Mersin Ticaret ve Sanayi Odas1 Lisesi & 100 & 14.3 \\
\hline Mahmut Arslan Anadolu Lisesi & 100 & 14.3 \\
\hline Dumlupınar Anadolu İmam Hatip Lisesi & 100 & 14.3 \\
\hline Fatma Aliye Mesleki ve Teknik Anadolu Lisesi & 100 & 14.3 \\
\hline Mersin Kiz Anadolu İmam Hatip Lisesi & 100 & 14.3 \\
\hline Sinif & $\mathrm{f}$ & $\%$ \\
\hline 9. $\sin 1 f$ & 175 & 25 \\
\hline 10. sinif & 175 & 25 \\
\hline 11. sinif & 175 & 25 \\
\hline 12. sinif & 175 & 25 \\
\hline Cinsiyet & $\mathrm{f}$ & $\%$ \\
\hline Kadın & 352 & 50,3 \\
\hline Erkek & 348 & 49,7 \\
\hline Yaş Grupları & $\mathrm{f}$ & $\%$ \\
\hline 14 yaş & 70 & 10 \\
\hline 15 yaş & 159 & 23 \\
\hline 16 yaş & 201 & 29 \\
\hline 17 yaş & 188 & 27 \\
\hline 18 yaş ve üstü & 82 & 11 \\
\hline Gelir Gruplar1 & $\mathrm{f}$ & $\%$ \\
\hline 2000 TL alt 1 & 243 & 34,7 \\
\hline 2000 ve 3000 TL aras 1 & 168 & 24 \\
\hline 3000 ve 4000 TL aras 1 & 130 & 18,6 \\
\hline 4000 TL üzeri & 159 & 22,7 \\
\hline Ailedeki kişi sayısı & $\mathrm{f}$ & $\%$ \\
\hline 2 kişi & 16 & 2,3 \\
\hline 3 kişi & 55 & 7,9 \\
\hline 4 kişi & 225 & 32,1 \\
\hline 5 kişi & 198 & 28,3 \\
\hline 6 ve üstü & 206 & 29,4 \\
\hline Toplam & 700 & 100 \\
\hline
\end{tabular}

\section{Veri toplama}

Araştırmanın verileri araştırmacı tarafindan geliştiren "Lise Öğrencilerinin Rol Model Tercihleri" adlı anket aracılığı ile toplanmıştır. Anket, araştırma soruları temelinde ve ilgili literatür taranarak ve uzman görüşü alınarak hazırlanmıştır. Anket formunda yer alan soruların anlaşılırlığı ve açıklığını belirleyebilmek için 50 öğrencinin katılımı ile bir pilot uygulama yapılmış ve anket yeniden düzenlenmiştir. Bu düzenlemeden sonra tekrar ettiği fark edilen maddeler çıkartılmıştır.

Anket formu dört bölümden oluşmaktadır. İlk bölümde yer alan sorularla öğrencilerin yaş, cinsiyet, sınıf, okul adı, aile kişi sayısı, aile gelir durumu ile ilgili bilgileri elde etmek amaçlanmıştır. İzleyen bölümde ise lise öğrencilerine beğendikleri, sevdikleri, örnek aldıkları, 
onun gibi olmak istedikleri kișilerin isimlerini meslekleriyle birliktel'den 5'e kadar siralayarak yazmaları istenmiştir. Üçüncü bölümde öğrencilerin örnek aldıkları rol modellerin özellikleri hakkındaki görüssleri, dördüncü bölümde de lise öğrencilerin rol modellerini tercih etme nedenlerine ilişkin görüşlerini tespit etmek için "kesinlikle katıllyorum", "katıllyorum", "kararsızım", "katılmıyorum" ve "kesinlikle katılmıyorum" yanıt seçeneklerinden oluşan toplam 31 soru sorulmuştur. Anketler gerekli yasal izinler alındıktan sonra 2018-2019 güz dönemi sonunda çalışma grubunda yer alan okullarda araştırmacı tarafından uygulanmıştır.

\section{Verilerin analizi}

Veriler önce kodlanmış ve SPSS paket programına yüklenmiştir. Araştırma alt problemleri izlenerek yürütülen frekans ve yüzdelik betimleyici istatistiksel teknikleri ve çapraz tablolar ile araştırmaya katılan lise öğrencilerinin rol model tercihleri incelenmiştir.

Anketin ikinci bölümünde öğrencilerden beğendikleri, sevdikleri, örnek aldıkları, onun gibi olmak istedikleri rol modeller açık uçlu soru şeklinde sorulmuş, elde edilen veriler analiz edilirken 10 farklı kategori üzerinden değerlendirilmiştir. Bu kategoriler öğrencilerin verdikleri yanıtlar çerçevesinde şu şekilde oluşmuştur:

Medya ünlüleri: medya endüstrisi tarafından oluşturulan, üretilen, popüler hale getirilen, Bilgisayar oyun karakterleri, sunucu-spiker, manken, sosyal medya fenomeni, çizgi animasyon film karakterleri, dizi-sinema oyuncuları, müzisyen, sporcu, moda tasarımc1s1, komedyen gibi kişilerden oluşmuştur.

Profesyonel meslek grupları: girişimci-işadamı, ressam, dansç1, mühendis, fotoğrafçı, doktor, ekonomist, pilot, gazeteci, asker-polis, felsefeci, sosyolog, avukat, işletmeci, yönetmen, savc1, hemşire gibi mesleklerden bireyleri kapsamıştır.

Tarihi karakterler: Türk tarihinde ön plana çıkmış, iz bırakmış, kişilik ve şahsiyetlerden oluşmuştur.

Edebi karakterler ve yazarlar: Hikâye-roman yazarları ve karakterlerinden oluşmuştur.

Aile bireyleri: Anne-baba, kardeş ve yakın akrabaları içermektedir.

Öğretmenler: Öğretmenlik mesleğini yapmış ve yapmakta olan kişileri kapsamıştır.

Bilim insanı: Bilim dünyasında geçmişte ve günümüzde ön plana çıkmış, iz bırakmış kişileri içermiştir.

Dini figür: Geçmişte ve günümüzde din alanında ön plana çıkmış, iz bırakmış kişilerden oluşmaktadır.

Arkadaş çevresi: Kişinin sevdiği, beğendiği, arkadaşlık kurduğu yakın çevresindeki kişilerden oluşmuştur.

Politikacı: Geçmişte ve günümüzde siyaset alanında ön plana çıkmış, iz bırakmış kişilerden oluşmaktadır.

\section{Bulgular}

Bu bölümde araştırma sorularını takip ederek önce lise öğrencilerinin rol model tercihlerini nasıl sıraladıkları, role model tercihlerine göre hangi alanlardan kişileri kendilerine örnek aldıkları, lise öğrencilerinin rol model tercihlerinin sınıf düzeylerine, gelir düzeylerine, cinsiyetlerine ve okullarına göre nasıl ayrıştığ modellerine yöneldiklerine ilişkin görüşleri incelenmiştir. Öğrencilerin hangi alanlardan kişileri kendilerine örnek aldıkları değerlendirilirken öğrencilerin rol model sıralamalarında ilk üç 
tercihlerine verdikleri yanıtlar dikkate alınmıştır. Öğrencilerin rol model tercihleri sınıf düzeylerine, gelir düzeylerine, cinsiyetlerine ve okullarına göre değerlendirilirken ise öğrencilerin rol model sıralamalarında ilk tercihlerine verdikleri yanıtlar dikkate alınmıştır.

\section{Lise öğrencilerinin rol model tercihleri}

Ankete katılan lise öğrencilerine açık uçlu soru olarak kimleri kendilerine örnek aldıkları 1, 2 ve 3. tercihler üzerinden belirtmeleri istenmiştir. Öğrencilerin verdikleri yanttlar çerçevesinde 10 temel kategori belirlenmiş ve öğrencilerin 1,2 ve 3 . tercihleri bu kategoriler üzerinden incelenmiştir.

Tablo 2.

Lise Öğrencilerinin Kimleri Tercih Etiğine İlişkin Frekans ve Yüzde Dağılımları

\begin{tabular}{lcccccc}
\hline & \multicolumn{2}{c}{ 1. Tercih } & \multicolumn{2}{c}{ 2. Tercih } & \multicolumn{2}{c}{ 3. Tercih } \\
\hline Alanlar & $\mathrm{f}$ & $\%$ & $\mathrm{f}$ & $\%$ & $\mathrm{f}$ & $\%$ \\
\hline Öğretmen & 27 & 3,9 & 45 & 6,4 & 35 & 5 \\
Aile Bireyi & 86 & 12,3 & 62 & 8,9 & 39 & 5,6 \\
Bilim İnsanı & 29 & 4,1 & 28 & 4 & 22 & 3,1 \\
Tarihi Karakter & 133 & 19 & 38 & 5,5 & 29 & 4,1 \\
Edebi Kärakter-Yazar & 34 & 4,9 & 42 & 6 & 29 & 4,1 \\
Medya Ünlüleri & 327 & 46,7 & 390 & 55,7 & 355 & 50,7 \\
Dini Figür & 17 & 2,4 & 8 & 1,1 & 3 & 0,4 \\
Arkadaş Çevresi & 1 & 0,1 & 8 & 1,1 & 5 & 0,4 \\
Politikac1 & 11 & 1,6 & 6 & 0,9 & 13 & 1,9 \\
Profesyonel Meslek Sahipleri & 35 & 5 & 39 & 5,6 & 32 & 4,6 \\
Cevapsiz & 0 & 0 & 34 & 4,9 & 138 & 19,7 \\
\hline Toplam & 700 & 100 & 700 & 100 & 700 & 100 \\
\hline
\end{tabular}

Öğrencilerin 1. tercihleri incelendiğinde en çok medya ünlülerini $(\% 46,7)$, sonra tarihi karakterleri (\% 19), aile bireylerini (\%12,3), profesyonel meslek gruplarındaki kişileri (\% 5), edebi karakter ve yazarları (\% 4,9), bilim insanlarını (\% 4,1), öğretmenleri (\%3,9), dini figürleri $(\% 2,4)$, politikacıları $(\% 1,6)$, arkadaş çevresini $(\% 0,1)$, tercih ettikleri görülmektedir. Lise öğrencileri medya ünlülerini ilk tercihlerinde \%46,7, ikinci tercihlerinde $\% 55,7$, üçüncü tercihlerinde ise \% 50,7 oranında yani her üç tercihte de öncelik olarak önemli oranlarda tercih ettikleri görülmektedir. Lise öğrencileri, aile bireylerini ilk tercihlerinde $\% 12,3$ oranında, ikinci tercihlerinde $\%$ 8,9, üçüncü tercihlerinde \% 5,6 oranında rol model olarak tercih ettiklerini ifade etmiş̧lerdir. Lise öğrencileri, öğretmenleri ilk tercihlerinde \% 3,9, ikinci tercihlerinde \% 6,4, üçüncü tercihlerinde $\% 5$ oranında tercih ettikleri görülmektedir. Bilim insanları, orta öğretim öğrencileri tarafından ilk tercihte \% 4,1, ikinci tercihlerinde \% 4, üçüncü tercihlerinde ise \% 3,1 oranında rol model olarak tercih edilmiştir.

$\mathrm{Bu}$ dağılımlardan lise öğrencilerinin rol model olarak birinci tercihlerinde medya ünlülerini rol model olarak tercih ettiklerini, ikinci olarak tarihi karakterleri, üçüncü olaraktan aile bireylerini rol model olarak benimsedikleri görülmektedir. Burada aile bireylerinin, öğretmenlerin, bilim insanlarının medya ünlülerine oranla daha düşük bir oranda tercih edilmesi dikkat çekici bir bulgudur. Yine dikkat çekici başka bir bulguda, lise öğrencilerinin arkadaş çevresini rol model olarak birinci tercihlerinde $\% 0,1$, ikinci tercihlerinde $\% 1,1$, üçüncü tercihlerinde $\% 0,4$ oranında tercih etmeleri olmuştur.

\section{Lise öğrencilerinin medya ünlülerini seçtikleri alanlar}

Araştırmaya katılan öğrencilerin rol model tercihlerinde ön plana çıkan medya ünlüleri kategorisini oluşturan alt alanların neler olduğu ayrıca incelenmiş ve dağılımları aşağıda verilmiş̧ir. 
Tablo 3.

Lise Öğrencilerinin Medya Ünlülerini Hangi Alandan Tercih Ettiklerine İlişkin Frekans ve Yüzde Dağılımları

\begin{tabular}{lcccccc}
\hline & \multicolumn{2}{c}{ 1.Tercih } & \multicolumn{2}{c}{ 2. Tercih } & \multicolumn{2}{c}{ 3. Tercih } \\
\hline Medya ünlüleri & $\mathrm{f}$ & $\%$ & $\mathrm{f}$ & $\%$ & $\mathrm{f}$ & $\%$ \\
\hline Bilgisayar oyun karakteri & 5 & 1,5 & 7 & 1,8 & 3 & 0,8 \\
Sporcular & 53 & 16,2 & 70 & 18 & 55 & 15,5 \\
Sunucu-spikerler & 13 & 4 & 21 & 5,4 & 11 & 3,2 \\
Müzisyenler & 96 & 29,3 & 115 & 29,5 & 132 & 37,2 \\
Mankenler & 6 & 1,9 & 10 & 2,5 & 2 & 0,5 \\
Sosyal medya fenomenleri & 12 & 3,7 & 14 & 3,6 & 15 & 4,2 \\
Çizgi-animasyon karakter & 4 & 1,2 & 10 & 2,5 & 5 & 1,4 \\
Dizi-sinema oyuncular1 & 125 & 38,3 & 141 & 36,1 & 125 & 35,2 \\
Komedyenler & 11 & 3,3 & 2 & 0,5 & 7 & 2 \\
Moda tasarımciları & 2 & 0,6 & 0 & 0 & 0 & 0 \\
\hline Toplam & 327 & 100 & 390 & 100 & 355 & 100 \\
\hline
\end{tabular}

Tabloyu incelediğimizde Lise öğrencilerinin medya alanında ilk tercihlerinde en çok dizi ve sinema oyuncularını $(\% 38,3)$, sonra müzisyenleri $(\% 29,3)$ üçüncü olarak sporcuları $(\% 16,2)$ oranında rol model olarak tercih ettiklerini ifade etmişlerdir. Lise öğrencileri ikinci tercihlerinde de en çok dizi ve sinema oyuncularını $(\% 36,1)$, müzisyenleri $(\% 29,5)$ ve sporcuları (\%18) tercih etmişlerdir. Üçüncü tercihler incelendiğinde yine dizi ve sinema oyuncularını $(\% 35,2)$, müzisyenleri $(\% 37,2)$, sporcuları $(\% 15,5)$ yüksek oranlarda tercih ettikleri görülmektedir. Bu bulgulardan hareketle lise öğrencilerinin medya ünlüleri olarak en çok dizi ve sinema oyuncularını, müzisyenleri ve sporcuları öncelikle rol model olarak tercih ettiklerini ifade etmek mümkündür.

Lise öğrencilerinin sınıf düzeyine göre rol model tercihleri

Lise öğrencilerinin rol model tercihlerinin sınıf düzeyine göre değişip değişmediği incelenmiştir.

Tablo 4.

Lise Öğrencilerinin Rol Model Tercihlerinin Sınıf Düzeyine Göre Frekans ve Yüzde Dağılımları

\begin{tabular}{lcccccc}
\hline Alanlar & & \multicolumn{4}{c}{ Sınıf } & Toplam \\
\cline { 2 - 6 } Öğretmen & 9. Sinıf & 10. Sınıf & 11. Sinıf & 12. Sınıf & \\
\cline { 2 - 6 } Aile Bireyi & $\mathrm{f}$ & 7 & 4 & 10 & 6 & 27 \\
& $\%$ & 1 & 0,6 & 1,4 & 0,9 & 3,9 \\
Bilim İnsanı & $\mathrm{f}$ & 11 & 20 & 30 & 25 & 86 \\
& $\%$ & 1,6 & 2,9 & 4,3 & 3,6 & 12,3 \\
Tarihi Karakter & $\mathrm{f}$ & 9 & 9 & 4 & 7 & 29 \\
& $\%$ & 1,3 & 1,4 & 0,6 & 1 & 4,1 \\
Edebi Karakter-Yazar & $\mathrm{f}$ & 29 & 36 & 36 & 32 & 133 \\
& $\%$ & 4 & 5,2 & 5,1 & 4,6 & 19 \\
Medya Ünlüleri & $\%$ & 7 & 9 & 9 & 9 & 34 \\
& $\mathrm{f}$ & 1 & 1,3 & 1,3 & 1,3 & 4,9 \\
Dini Figür & $\%$ & 14,4 & 11,1 & 10,1 & 11 & 327 \\
& $\mathrm{f}$ & 2 & 3 & 5 & 7 & 46,7 \\
Arkadaş Çevresi & $\%$ & 0,3 & 0,4 & 0,7 & 1 & 2,4 \\
& $\mathrm{f}$ & 1 & 0 & 0 & 0 & 1 \\
& $\%$ & 0,1 & 0 & 0 & 0 & 0,1 \\
\hline
\end{tabular}




\begin{tabular}{lcccccc}
\hline Politikac1 & $\mathrm{f}$ & 3 & 3 & 3 & 2 & 11 \\
& $\%$ & 0,4 & 0,4 & 0,4 & 0,3 & 1,6 \\
Profesyonel Meslek & $\mathrm{f}$ & 5 & 13 & 7 & 10 & 35 \\
Sahipleri & $\%$ & 0,7 & 1,9 & 1 & 1,4 & 5 \\
\hline Toplam & $\mathrm{f}$ & 175 & 175 & 175 & 175 & 700 \\
& $\%$ & 25 & 25 & 25 & 25 & 100 \\
\hline
\end{tabular}

Lise öğrencilerinin rol model tercihlerinin sınıf düzeyine göre değişip değişmediği bu kez sadece birinci tercihleri üzerinden değerlendirilmiştir. 9., 10., 11. ve 12. sinıfların rol model tercihlerinde ilk üç sırayı medya ünlüleri, tarihi karakterler ve aile bireyleri almıştır. Tablonun genelini incelediğimizde lise öğrencilerinin rol model tercihlerinde oranların birbirine yakın olduğu sınıf düzeyine göre ciddi bir değişim göstermediği görülmektedir.

\section{Lise öğrencilerinin gelir durumlarına göre rol model tercihleri}

Lise öğrencilerinin rol model tercihlerinin gelire göre değişip değişmediği öğrencilerin rol modeline ilişkin ilk tercihlerine göre değerlendirilmiştir.

Tablo 5.

Lise Öğrencilerinin Rol Model Tercihlerinin Gelire Göre Frekans ve Yüzde Dağılımları

\begin{tabular}{|c|c|c|c|c|c|c|}
\hline \multirow[t]{2}{*}{ Alanlar } & & \multicolumn{4}{|c|}{ Gelir } & \multirow[t]{2}{*}{ Toplam } \\
\hline & & $\begin{array}{c}\text { 2000TL } \\
\text { Alt1 }\end{array}$ & $\begin{array}{c}2000-3000 \\
\text { TL aras1 }\end{array}$ & $\begin{array}{c}3000-4000 \\
\text { TL aras } 1\end{array}$ & $\begin{array}{l}4000 \mathrm{TL} \\
\text { ve üzeri }\end{array}$ & \\
\hline \multirow{2}{*}{ Öğretmen } & $\mathrm{f}$ & 13 & 7 & 7 & 0 & 27 \\
\hline & $\%$ & 1,9 & 1 & 1 & 0 & 3,9 \\
\hline \multirow{2}{*}{ Aile Bireyi } & $\mathrm{f}$ & 31 & 19 & 17 & 19 & 86 \\
\hline & $\%$ & 4,4 & 2,7 & 2,4 & 2,7 & 12,3 \\
\hline \multirow[t]{2}{*}{ Bilim İnsanı } & $\mathrm{f}$ & 7 & 5 & 7 & 10 & 29 \\
\hline & $\%$ & 1 & 0,7 & 1 & 1,4 & 4,1 \\
\hline \multirow[t]{2}{*}{ Tarihi Karakter } & $\mathrm{f}$ & 29 & 36 & 23 & 45 & 133 \\
\hline & $\%$ & 4,1 & 5,1 & 3,3 & 6,4 & 19 \\
\hline \multirow[t]{2}{*}{ Edebi Karakter-Yazar } & $\mathrm{f}$ & 12 & 7 & 8 & 7 & 34 \\
\hline & $\%$ & 1,7 & 1 & 1,1 & 1 & 4,9 \\
\hline \multirow[t]{2}{*}{ Medya Ünlüleri } & $\mathrm{f}$ & 127 & 81 & 67 & 52 & 327 \\
\hline & $\%$ & 18,1 & 11,6 & 9,6 & 7,4 & 46,7 \\
\hline \multirow[t]{2}{*}{ Dini Figür } & $\mathrm{f}$ & 8 & 3 & 3 & 3 & 17 \\
\hline & $\%$ & 1,1 & 0,4 & 0,4 & 0,4 & 2,4 \\
\hline \multirow[t]{2}{*}{ Arkadaş Çevresi } & $\mathrm{f}$ & 0 & 1 & 0 & 0 & 1 \\
\hline & $\%$ & 0 & 0,1 & 0 & 0 & 0,1 \\
\hline \multirow[t]{2}{*}{ Politikacı } & $\mathrm{f}$ & 4 & 4 & 1 & 2 & 11 \\
\hline & $\%$ & 0,6 & 0,6 & 0,1 & 0,3 & 1,6 \\
\hline \multirow[t]{2}{*}{ Profesyonel Meslek Sahipleri } & $\mathrm{f}$ & 9 & 5 & 12 & 9 & 35 \\
\hline & $\%$ & 1,3 & 0,7 & 1,7 & 1,3 & 5 \\
\hline \multirow[t]{2}{*}{ Toplam } & $\mathrm{f}$ & 240 & 168 & 145 & 147 & 700 \\
\hline & $\%$ & 34,3 & 24 & 20,7 & 21 & 100 \\
\hline
\end{tabular}

Tabloyu incelediğimizde tüm gelir gruplarından öğrencilerin rol model tercihlerinin ilk sırasında farklı oranlarda olmakla birlikte medya ünlülerinin yer aldığı görülmektedir. Medya ünlülerini en çok \% 18,1 oranında $2.000 \mathrm{TL}$ altı gelir grubundan öğrenciler tercih ederken en az oranda ise $\% 7,4$ ile 4.000 TL üstü gelir grubundaki öğrenciler tercih etmişlerdir. Lise öğrencilerinin rol model olarak öğretmen tercihleri incelendiğinde ise gelire göre önemli bir değişim olmadığı, ancak öğretmenleri rol model olarak tercih etme oranının 2.000 TL altı gelir grubunda daha yüksek olduğu görülmektedir. 
Yine aile bireylerini rol modeli olarak tercih etme oranları incelendiğinde gelir grupları arasında önemli bir ayrışma olmamakla birlikte $2.000 \mathrm{TL}$ altı gelir grubuna sahip öğrencilerin diğer gelir gruplarına oranla aile bireylerini daha çok rol model olarak tercih ettiği izlenmektedir. Bilim insanlarını rol modeli olarak öncelikle tercih edenlerin 4.000 TL ve üstü gelir grubundan öğrenciler oldukları görülmektedir. Benzer biçimde tarihi karakterlerin, 4.000TL ve üzeri gelir grubundaki öğrenciler tarafından öncelikle tercih edildiği görülmektedir. Dini figürleri öncelikle tercih edenler ise $2.000 \mathrm{TL}$ altı gelir grubundan öğrenciler olmuştur.

\section{Lise öğrencilerinin cinsiyetlerine göre rol model tercihleri}

Lise öğrencilerinin rol model tercihlerinin cinsiyete göre değişip değişmediği incelenmiş ve dağılımlar aşağıdaki tabloda gösterilmiştir.

Tablo 6.

Lise Öğrencilerinin Rol Model Tercihlerinin Cinsiyete Göre Frekans ve Yüzde Dağılımları

\begin{tabular}{|c|c|c|c|c|c|c|}
\hline \multirow{4}{*}{ Alanlar } & \multicolumn{4}{|c|}{ Cinsiyet } & \multicolumn{2}{|c|}{ Toplam } \\
\hline & & & & & f & $\%$ \\
\hline & \multicolumn{2}{|c|}{ Kadın } & \multicolumn{2}{|c|}{ Erkek } & & \\
\hline & $\mathrm{f}$ & $\%$ & $\mathrm{f}$ & $\%$ & & \\
\hline Öğretmen & 14 & 2 & 13 & 1,9 & 27 & 3,9 \\
\hline Aile Bireyi & 54 & 7,7 & 32 & 4,6 & 86 & 12,3 \\
\hline Bilim İnsanı & 16 & 2,3 & 13 & 1,9 & 29 & 4,1 \\
\hline Tarihi Karakter & 79 & 11,3 & 54 & 7,7 & 133 & 19 \\
\hline Edebi Karakter-Yazar & 27 & 3,9 & 7 & 1 & 34 & 4,9 \\
\hline Medya Ünlüleri & 139 & 19,9 & 188 & 26,9 & 327 & 46,7 \\
\hline Dini Figür & 4 & 0,6 & 13 & 1,9 & 17 & 2,4 \\
\hline Arkadaş Çevresi & 0 & 0 & 1 & 0,1 & 1 & 0,1 \\
\hline Politikacı & 2 & 0,3 & 9 & 1,3 & 11 & 1,6 \\
\hline $\begin{array}{l}\text { Profesyonel Meslek } \\
\text { Sahipleri }\end{array}$ & 17 & 2,4 & 18 & 2,6 & 35 & 5 \\
\hline Toplam & 352 & 50,3 & 348 & 49,7 & 700 & 100 \\
\hline
\end{tabular}

Tabloyu incelediğimizde kadın ve erkek öğrencilerin ilk üç rol modeli tercihlerinin benzer biçimde medya ünlüleri, tarihi karakter ve aile bireyi olarak sıralandığı görülmektedir. Az farkla da olsa kadınların erkeklere oranla öğretmenleri daha çok rol modeli olarak tercih ettikleri görülmektedir. Benzer eğilim aile bireyleri içinde sürmüş ve aile bireylerini rol model olarak tercih edenler arasında kadınların oranı $\% 8$, erkeklerin $\% 5$ oranında olmuştur. Bilim insanlarını rol model olarak tercih edenler arasında kadınların oranı \%2,3, erkeklerin ise \%1,9 olmuştur. Tarihi karakter, edebi karakter ve yazar rol model tercihlerinde de benzer biçimde kadınların tercih etme oranlarının erkeklerden daha yüksek olduğu gözlemlenmiştir. Medya ünlüleri, dini figür, politikacı kategorilerini ise erkeklerin tercih etme oranlarının kadınlara oranla daha yüksek olduğu izlenmektedir.

\section{Lise öğrencilerinin devam ettikleri okullara göre rol model tercihleri}

Öğrencilerin devam ettikleri okula göre rol model tercihlerine ilişkin dağılım aşağıdaki tabloda sunulmuștur.

Lise öğrencilerinin rol model tercihlerinin devam ettikleri okullara göre değișip değişmediği değerlendirilmiștir. Tabloyu incelediğimizde medya ünlülerini tercih eden $\% 46,7^{\prime}$ lik oran okullar açısından en yüksekten en aza doğru sıralandığında; öğrencilerin Mersin Mesleki ve Teknik Anadolu Lisesinde \%9,4, Dumlupınar Anadolu İmam Hatip Lisesinde \%8,4, Şevket Pozcu Anadolu Lisesinde \%6,9, Fatma Aliye Mesleki ve Teknik Anadolu Lisesinde \%6,6, Mersin Ticaret ve Sanayi Odas1 Anadolu Lisesinde \%5,7, Mahmut Aslan Anadolu Lisesinde \%5,3, İçel Anadolu Lisesinde \%4,4 oranlarında tercih yaptıkları görülmektedir. 
Tablo 7.

Lise Öğrencilerinin Rol Model Tercihlerinin Devam Ettikleri Okullara Göre Frekans ve Yüzde Dağılımları

\begin{tabular}{|c|c|c|c|c|c|c|c|c|c|}
\hline \multirow[t]{2}{*}{ Alanlar } & \multicolumn{8}{|c|}{ Okul } & \multirow[t]{2}{*}{ Toplam } \\
\hline & & Ş.P & İ.A & D.İ.H & M.A & MTSO & F.A & MMT & \\
\hline \multirow{2}{*}{ Öğretmen } & $\mathrm{f}$ & 10 & 1 & 1 & 4 & 1 & 3 & 7 & 27 \\
\hline & $\%$ & 1,4 & 0,1 & 0,1 & 0,6 & 0,1 & 0,4 & 1 & 3,9 \\
\hline \multirow{2}{*}{ Aile Bireyi } & $\mathrm{f}$ & 12 & 15 & 7 & 8 & 11 & 20 & 13 & 86 \\
\hline & $\%$ & 1,7 & 2,1 & 1 & 1,1 & 1,6 & 2,9 & 1,9 & 12,3 \\
\hline \multirow{2}{*}{ Bilim İnsanı } & $\mathrm{f}$ & 2 & 4 & 4 & 9 & 3 & 6 & 1 & 29 \\
\hline & $\%$ & 0,3 & 0,6 & 0,6 & 1,3 & 0,4 & 0,9 & 0,1 & 4,1 \\
\hline \multirow{2}{*}{ Tarihi Karakter } & $\mathrm{f}$ & 19 & 39 & 7 & 25 & 25 & 15 & 3 & 133 \\
\hline & $\%$ & 2,7 & 5,6 & 1 & 3,6 & 3,6 & 2,1 & 0,4 & 19 \\
\hline \multirow[t]{2}{*}{ Edebi Karakter-Yazar } & $\mathrm{f}$ & 4 & 4 & 3 & 5 & 11 & 6 & 1 & 34 \\
\hline & $\%$ & 0,6 & 0,6 & 0,4 & 0,7 & 1,6 & 0,9 & 0,1 & 4,9 \\
\hline \multirow[t]{2}{*}{ Medya Ünlüleri } & $f$ & 48 & 31 & 59 & 37 & 40 & 46 & 66 & 327 \\
\hline & $\%$ & 6,9 & 4,4 & 8,4 & 5,3 & 5,7 & 6,6 & 9,4 & 46,7 \\
\hline \multirow[t]{2}{*}{ Dini Figür } & $f$ & 4 & 0 & 9 & 2 & 1 & 0 & 1 & 17 \\
\hline & $\%$ & 0,6 & 0 & 1,3 & 0,3 & 0,1 & 0 & 0,1 & 2,4 \\
\hline \multirow[t]{2}{*}{ Arkadaş Çevresi } & $\mathrm{f}$ & 1 & 0 & 0 & 0 & 0 & 0 & 0 & 1 \\
\hline & $\%$ & 0,1 & 0 & 0 & 0 & 0 & 0 & 0 & 0,1 \\
\hline \multirow[t]{2}{*}{ Politikacı } & $f$ & 0 & 1 & 3 & 2 & 3 & 0 & 0 & 11 \\
\hline & $\%$ & 0 & 0,1 & 0,4 & 0,3 & 0,4 & 0 & 0 & 1,6 \\
\hline Profesyonel Meslek & $\mathrm{f}$ & 0 & 5 & 7 & 8 & 5 & 4 & 6 & 35 \\
\hline Sahipleri & $\%$ & 0 & 0,7 & 1 & 1,1 & 0,7 & 0,6 & 0,9 & 5 \\
\hline \multirow[t]{2}{*}{ Toplam } & $f$ & 100 & 100 & 100 & 100 & 100 & 100 & 100 & 700 \\
\hline & $\%$ & 14,3 & 14,3 & 14,3 & 14,3 & 14,3 & 14,3 & 14,3 & 100 \\
\hline
\end{tabular}

Not: Tabloda kısaltma şeklinde yer alan okul isimleri karşılıkları şu şekildedir: Şevket Pozcu Anadolu Lisesi (Ş.P), İçel Anadolu Lisesi (İ.A), Dumlupınar Anadolu İmam Hatip Lisesi (D.İ.H), Mahmut Aslan Anadolu Lisesi (M.A), Mersin Ticaret ve Sanayi Odası Anadolu Lisesi (M.T.S.O), Fatma Aliye Mesleki ve Teknik Anadolu Lisesi (F.A), Mersin Mesleki ve Teknik Anadolu Lisesi (M.M.T).

Öğretmenleri rol modeli olarak tercih eden \%3,9'luk grup içerisinde ise en çok \%1,4 oranında Şevket Pozcu Anadolu Lisesi ögrencileri ve \%1 oranında Mersin Mesleki ve Teknik Anadolu Lisesi öğrencileri yer almıştır. Tarihi karakterleri tercih eden \%19'luk oran içerisinde en çok \%5,6 oranında İçel Anadolu lisesi öğrencileri ve \%3,6 oranında Mersin Ticaret ve Sanayi Odası Anadolu Lisesi öğrencileri ile Mahmut Aslan Anadolu Lisesi öğrencileri bulunmaktadır. Edebi karakter ve yazar kategorisini tercih eden \%4,9'luk oran içerisinde ise Mersin Ticaret ve Sanayi Odası Anadolu Lisesi ögrencileri \%1,6 oranıyla ilk sırada yer almıştır.

\section{Lise öğrencilerin tercih ettikleri rol modellerin özellikleri hakkındaki görüşleri}

Lise öğrencilerinin tercih ettikleri rol modellerin özellikleri hakkındaki görüşleri davranış, düşünce, giyim tarzı, meslekler gibi 10 temel özellik üzerinden ele alınmıştır. Lise öğrencilerinin tercih ettikleri rol modellerin özellikleri hakkındaki görüşleri, kesinlikle kat1lıyorum -katıllyorum ile kesinlikle katılmıyorum- katılmıyorum cevap tercihleri birlikte değerlendirilerek incelenmiştir.

Öğrencilerin \% 78,3'ünün model aldıkları kişilerin davranışlarını örnek aldıklarını ifade ettikleri görülmektedir. Öğrenciler \% 7,7 oranında model aldıkları kişilerin davranışlarını örnek almadıklarını, \%14'ü ise kararsız olduklarını ifade etmişlerdir. 
Tablo 8.

Lise Öğrencilerin Tercih Ettikleri Rol Modellerin Özellikleri Hakkındaki Görüşlerine İlişkin Frekans ve Yüzde Dă̆glımları

Rol model olarak beğendiğim kişilerin

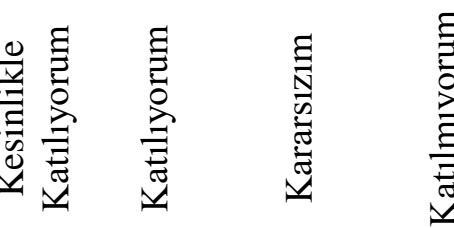

\section{Davranışlarını örnek alırım.}

2. Fikir ve düşüncelerine önem veririm.

3. Giyim tarzlarını kendime örnek alırım.

4. Yaptıkları mesleğin, gelecekte benimde mesleğim olmasını isterim.

5. Hayatları hakkında araştırma yaparım.

6. Hakkında sosyal medyada bilgi, fotoğraf, video vb. paylaşım yaparım. 7. Bilimsel, entelektüel kültürümü artırdığını düșünüyorum.

8.Kullandıkları ürünleri ben de kullanmak isterim.

9. Kişiliğini kendime örnek alırım.

10. Söylediği sözlere değer veririm.

$276 \quad 272$

$39,4 \quad 38,9$

f $\quad 341 \quad 280$

$\% \quad 48,7$

f $\quad 144$

$\% \quad 20,6$

f $\quad 201$

$\% \quad 28,7$

f $\quad 260$

$\% \quad 37,1$

f $\quad 153$

$\% \quad 21,9$

f $\quad 220$

$\% \quad 31,4$

f $\quad 184$

$\% \quad 26,3$

f $\quad 260$

$\% \quad 37,1$

f $\quad 354$

$\% \quad 50,6$

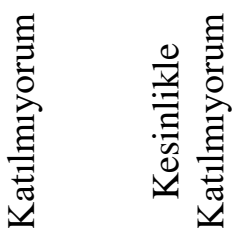

\begin{tabular}{ccc}
98 & 33 & 21 \\
14 & 4,7 & 3 \\
55 & 15 & 9 \\
7,9 & 2,1 & 1,3 \\
187 & 158 & 55 \\
26,7 & 22,6 & 7,9 \\
234 & 95 & 28 \\
33,4 & 13,6 & 4 \\
107 & 60 & 22 \\
15,3 & 8,6 & 3,1 \\
106 & 178 & 106 \\
15,1 & 25,4 & 15,1 \\
166 & 65 & 23 \\
23,7 & 9,3 & 3,3 \\
164 & 127 & 56 \\
23,4 & 18,1 & 8 \\
102 & 59 & 32 \\
14,6 & 8,4 & 4,6 \\
70 & 27 & 12 \\
10 & 3,9 & 1,7 \\
\hline
\end{tabular}

Lise öğrencilerinin model aldıkları kişilerin fikir ve düşüncelerine önem veririm düşüncesine katılanların oranı, öğrencilerin \%89'u model olarak benimsedikleri kişilerin fikir ve düşüncelerine önem verdiklerini belirtmiștir. \%3,5 oranında önem vermediklerini, \% 7,5 ise kararsız olduklarını ifade etmiștir.

Öğrencilerin \%43’ü model aldıkları kişilerin giyim tarzlarını kendilerine örnek aldığını, $\% 26,5$ 'i giyim tarzlarını örnek almadıklarını, \%30,5'i ise bu konuda kararsız olduklarını belirtmişlerdir. Öğrenciler rol model aldıkları kișilerin mesleğinin gelecekte kendi mesleklerinin olmasını istediğini belirtenlerin oranı $\% 49$, istemeyenlerin oranı $\% 17,5$, kararsız olduklarını belirtenlerin oranı ise $\% 33,5$ oranında olmuştur.

Lise öğrencilerinin model aldıkları kişiler hakkında sosyal medyada araştırma yaparım diyenlerin oran $1 \% 73$, araştırma yapmayanların oran $1 \% 11,7$, kararsız olduklarını belirtenler ise $\% 15,3$ oranında olmuştur. Öğrencilerin \%44,3'ü model aldıkları kişiler ile ilgili sosyal medyada bilgi, fotoğraf, video vb. paylaşım yaptığını, \%40,5'i, paylaşım yapmadıklarını, \% 15,2'si ise kararsız olduklarını belirtmiştir. Öğrencilerin \%63,7'si model aldıkları kişilerin kendi bilimsel entelektüel kültürlerini artırdığını, \%12,6'sı artırmadığını, \%23,7'si ise bu konuda kararsız olduklarını ifade etmiștir. Lise öğrencilerinin model aldıkları kişilerin kullandığı ürünleri kullanmak istediğini belirtenlerin oran1 \%50,4, kullanmak istemediklerini belirtenlerin oranı $\% 23,5$, kararsız oldukların belirtenlerin oranı ise \%26,1 olmuştur.

Lise öğrencilerinin \%72,4’ü model aldıkları kişilerin kişiliğini kendine örnek aldığını, \%14,6'sı kişiliklerini örnek almadıklarını, \%13'ü ise kararsız olduklarını belirtmişlerdir. Öğrencilerin \%84,5'i, model aldıkları kişilerin sözlerine değer verdiğini, \%5'i değer vermediğini, \%10’u ise kararsız olduklarını ifade etmiştir. 
Lise öğrencilerin rol modellerini tercih etme nedenleri

Lise öğrencilerin rol modellerini tercih etme nedenleri hakkındaki görüşleri 21 özellik üzerinden incelenmiştir. Lise öğrencilerin rol modellerini tercih etme nedenleri hakkındaki görüşleri, kesinlikle katılıyorum - katılıyorum ile kesinlikle katılmıyorum - katılmıyorum cevap tercihleri birlikte değerlendirilerek incelenmiştir.

Tablo 9.

Lise Öğrencilerin Rol Modellerini Tercih Etme Nedenlerine İlişkin Frekans ve Yüzde Dağılımları

Rol model olarak benimsediğim kişiyi veya kişileri tercih etme nedeni
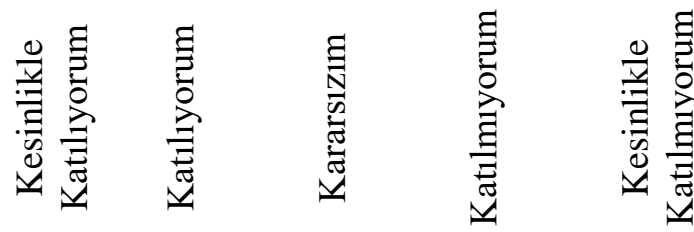

1. Fiziksel özelliği

204

169

117

125

2. Giyim tarzı

3. Esprili olmas1

4. Yardımsever olması

5. Bilgili olmas1

6. Karizmatik olması

7. Duygusal olmas1

8. Adil olmas1

9.Hirsl1 olmas1

10. Ak1llı olmas1

11.Özgür olmas1

12.Yaratic1 olmas1

13.Kurtaric1 olmas1

14. Güvenilir olması

15.Savaşçı olması

16.Sorun çözebilmesi

17.Vatansever olmas1

18.Cesur olmas1

19.Zengin olmas1

$\% \quad 29$

$$
24,2
$$

16,7

17,9

85

f $\quad 169$

$$
230
$$

110

121

15,7

17,1

$\% \quad 24,1$

32,2

140

84

10

f $\quad 217$

$$
\begin{gathered}
223 \\
31
\end{gathered}
$$

$$
20
$$

12

\section{4}

12

76

29

$80 \quad 21$

$10,3 \quad 3$

1,6

$302 \quad 203$

119

61

15

$\% \quad 43,1$

29

17

8,7

2,1

f $\quad 353$

212

91

29

$\% \quad 50,4 \quad 30,3$

13

4,1

2,2

f $\quad 243 \quad 179$

$\%$$$
\begin{aligned}
& 179 \\
& 25,6
\end{aligned}
$$

155

$155 \quad 75$

22,1

10,7

48

348

231

348
49,7

231

74

36

6,9

$\%$

$\begin{array}{llll}187 & 99 & 36 & 14\end{array}$

10,6

5,1

1,6

$\begin{array}{cccc}187 & 99 & 36 & 14 \\ 26,7 & 14,1 & 5,1 & 2\end{array}$

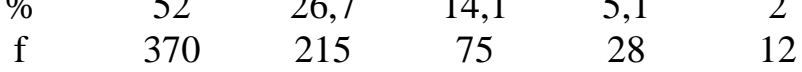

$\begin{array}{cccccc}\% & 370 & 215 & 75 & 28 & 12 \\ \mathrm{f} & 52,9 & 30,7 & 10,7 & 4 & 1,7\end{array}$

145

87

$132 \quad 144$

192 


\begin{tabular}{lcccccc}
\hline & $\%$ & 20,7 & 12,4 & 18,9 & 20,6 & 27,4 \\
20. Şöhretli olmas1 & $\mathrm{f}$ & 156 & 113 & 113 & 144 & 174 \\
21. Mesleği & $\%$ & 22,3 & 16,1 & 16,1 & 20,6 & 24,9 \\
& $\mathrm{f}$ & 315 & 174 & 101 & 54 & 56 \\
& $\%$ & 45 & 24,9 & 14,4 & 7,7 & 8 \\
\hline
\end{tabular}

Lise öğrencilerinin rol modellerini tercih etme nedenleri incelendiğinde öğrencilerin fiziksel özelliğinden dolayı rol modelleri tercih edenlerin oranı \%53, fiziksel özelliğinden dolayı tercih etmeyenlerin oranı $\% 30$, kararsız olduklarını belirtenlerin oranı ise $\% 17$ olmuştur. Giyim tarzından dolay1 rol model tercih edenlerin oran1 \%56, giyim tarzından dolay1 tercih etmediklerini belirtenlerin oran $\% 18$, kararsız olduklarını ifade edenlerin oranı ise $\% 16$ olmuştur. Rol modellerini esprili olmasından dolayı tercih edenlerin oranı $\% 63$, bundan dolay1 tercih etmeyenlerin oranı \% 17 , kararsız olduklarını belirtenlerin oranı ise \%20 olmuştur. Rol modellerinin yardımsever olmasından dolayı tercih edenlerin oranı $\% 85$, bundan dolayı tercih etmeyenlerin oranı $\% 6$, kararsız olduklarını belirtenlerin oranı ise $\% 9$ olmuştur.

Rol modellerini bilgili olmasından dolayı tercih edenlerin oran $\% 88$, bundan dolay 1 tercih etmeyenlerin oranı $\% 4$, kararsız olduklarını belirtenlerin oranı ise $\% 8$ olmuștur. Rol modellerini karizmatik olmasından dolayı tercih edenlerin oranı $\% 62$, bundan dolay1 tercih etmeyenlerin oranı $\% 21$, kararsız olduklarını belirtenlerin oranı ise $\% 17$ olmuştur. Rol modellerini duygusal olmasindan dolayı tercih edenlerin oranı $\% 53$, bundan dolay1 tercih etmeyenlerin oranı \%17, kararsız olduklarını belirtenlerin oranı ise \%26 olmuştur. Rol modellerini adil olmasından dolayı tercih edenlerin oran1 \%83, bundan dolay1 tercih etmeyenlerin oranı $\% 6$, kararsız olduklarını belirtenlerin oranı ise \%11 olmuştur. Rol modellerini hırslı olmasından dolay 1 tercih edenlerin oran $\% 75$, bundan dolay 1 tercih etmeyenlerin oranı \%10, kararsız olduklarını belirtenlerin oranı ise $\% 15$ olmuştur. Rol modellerini akıllı olmasından dolayı tercih edenlerin oran1 $\% 90$, bundan dolay1 tercih etmeyenlerin oranı $\% 3$, kararsız olduklarını belirtenlerin oranı ise $\% 7$ olmuştur.

Rol modellerini özgür olmasından dolayı tercih edenlerin oranı $\% 85$, bundan dolay 1 tercih etmeyenlerin oran $1 \% 4$, kararsız olduklarını belirtenlerin oranı ise $\% 11$ olmuştur. Rol modellerini yaratıcı olmasından dolay1 tercih edenlerin oran1 $\% 85$, bundan dolay1 tercih etmeyenlerin oranı $\% 5$, kararsız olduklarını belirtenlerin oranı ise $\% 10$ olmuştur. Rol modellerini kurtarıc1 olmasından dolayı tercih edenlerin oran1 \%72, bundan dolay1 tercih etmeyenlerin oranı \%11, kararsız olduklarını belirtenlerin oranı ise \%17 olmuştur. Rol modellerini güvenilir olmasından dolayı tercih edenlerin oranı $\% 81$, bundan dolayı tercih etmeyenlerin oranı \%7, kararsız olduklarını belirtenlerin oranı ise \%13 olmuştur. Rol modellerinin savaşçı olmasından dolayı tercih edenlerin oranı $\% 60$, bundan dolayı tercih etmeyenlerin oranı $\% 18$, kararsız olduklarını belirtenlerin oranı ise $\% 22$ olmuştur. Rol modellerini sorun çözebilmesinden dolayı tercih edenlerin oranı $\% 83$, bundan dolayı tercih etmeyenlerin oranı $\% 7$, kararsız olduklarını belirtenlerin oranı ise $\% 10$ olmuştur. Rol modellerini vatansever olmasindan dolayı tercih edenlerin oranı $\% 79$, bundan dolay1 tercih etmeyenlerin oranı $\% 7$, kararsız olduklarını belirtenlerin oranı ise \%14 olmuştur. Rol modellerini cesur olmasından dolay1 tercih edenlerin oran1 $\% 84$, bundan dolay1 tercih etmeyenlerin oranı \%6, kararsız olduklarını belirtenlerin oranı ise \%11 olmuștur. Rol modellerini zengin olmasından dolayı tercih edenlerin oran1 \%33, bundan dolayı tercih etmeyenlerin oranı \%48, kararsız olduklarını belirtenlerin oranı ise \%19 olmuştur. Rol modellerini şöhretli olmasından dolayı tercih edenlerin oranı $\% 38$, bundan dolayı tercih etmeyenlerin oranı \%46, kararsız olduklarını belirtenlerin oranı ise \%16 olmuştur. Rol modellerini mesleğinden dolayı tercih edenlerin oran $1 \% 70$, bundan dolayı tercih etmeyenlerin oranı $\% 16$, kararsız olduklarını belirtenlerin oranı ise $\% 14$ olmuştur.

$\mathrm{Bu}$ verilerden hareketle lise öğrencilerinin rol modellerini tercih ederken, kesinlikle katılıyorum ve katıllyorum kategorileri birlikte değerlendirildiğinde, rol modellerinin akı1lı olması $\% 90$, bilgili olması $\% 88$, yardımsever, özgür ve yaratıcı olması $\% 85$, cesur olmas1 $\% 84$, 
adil olmas1 $\% 83$, sorun çözebilmesi $\% 83$, güvenilir olmas $\% 81$, vatansever olması $\% 79$, hırslı olması \%75, kurtarıcı olması \%72, mesleği \%70 nedenlerine sirasıyla öncelik verdikleri görülmüştür. Daha sonra sirasıyla esprili olması \%63, karizmatik olmas1 \%62, savaşçı olması $\% 60$, giyim tarzı $\% 56$, fiziksel özelliği ve duygusal olmas1 \%53, şöhretli olmas1 \%38, zengin olması \%33 nedenlerine katıldıklarını belirtmişlerdir.

\section{Sonuç ve Değerlendirme}

Lise öğrencilerinin rol model tercihlerine ilişkin yapılan bu çalışmada elde edilen bulgular doğrultusunda şu sonuçlara ulaşılmıştır:

1. Lise öğrencilerine açık uçlu soru olarak kimleri kendilerine örnek aldıkları 1. 2. ve 3. tercihler üzerinden belirtmeleri istenmiştir. Öğrencilerin verdikleri yanıtlar çerçevesinde 10 temel kategori belirlenmiştir. Lise öğrencilerin 1. 2. ve 3. tercihleri bu kategoriler üzerinden incelendiğinde lise öğrencilerin sirasıyla;

İlk tercihlerinde medya ünlülerini \%46,7, tarihi karakterleri \%19, aile bireylerini\% $\% 12,3$, profesyonel meslek gruplarındaki kişileri $\% 5$, öğretmenleri $\% 3,9$, edebi karakter ve yazarları $\% 4,9$, bilim insanlarını $\% 4,1$, politikacıları $\% 1,6$, dini figürleri $\% 2,4$, arkadaş çevresindeki kişileri \%0,1 oranlarında rol model olarak tercih ettikleri görülmüştür. Lise öğrencilerin 2. tercihlerinde medya ünlülerini $\% 55,7$, tarihi karakterleri $\% 4,1$, aile bireylerini $\% 5,6$, profesyonel meslek gruplarındaki kişileri $\% 4,6$, öğretmenleri $\% 5$, edebi karakter ve yazarları $\% 4,1$, bilim insanlarını \%3,1, politikacıları \%1,9, dini figürleri \%0,4, arkadaş çevresindeki kişileri \% 0,4 oranlarında rol model olarak tercih ettikleri görülmüştür. Lise öğrencilerin 3. tercihlerinde medya ünlülerini $\% 50,7$, tarihi karakterleri $\% 5,5$, aile bireylerini $\% 8,9$, profesyonel meslek gruplarındaki kişileri $\% 5,6$, öğretmenleri $\% 6,4$, edebi karakter ve yazarları $\% 6$, bilim insanlarını $\% 4$, politikacıları $\% 0,9$, dini figürleri $\% 1,1$, arkadaş çevresindeki kişileri $\% 1,1$ oranlarında rol model olarak tercih ettikleri görülmüştür.

Lise öğrencileri medya ünlülerini oldukça yüksek bir oranda rol model olarak tercih ederken aile bireylerini, tarihi karakterleri, profesyonel meslek grubundaki kişileri, bilim insanlarını, öğretmenleri, edebi karakter ve yazarları rol model olarak tercih etme oranları düşüktür. Lise öğrencilerinin politikacıları, dini figürleri, arkadaş çevresindeki kişileri rol model olarak tercih etme oranları ise oldukça düşüktür.

2. Lise öğrencilerinin medya alanında en çok sirasıyla dizi-sinema oyuncuları, müzisyenler ve sporcuları rol model olarak tercih ettikleri görülmektedir. Öğrencilerin medya ünlülerini alanlara göre tercihleri ise şu şekilde olmuştur:

Lise öğrencilerin 1. tercihlerinde dizi-sinema oyuncuları \%38,3, müzisyenler \%29,3, sporcular $\% 16,2$, sunucu-spikerler $\% 4$, mankenler $\% 1,9$, sosyal medya fenomenleri $\% 3,7$, çizgianimasyon karakterleri \%1,2, bilgisayar oyun karakterleri \%1,5, komedyenler \%3,3, moda tasarımcıları \%0,6 oranında tercih etmişlerdir. Lise öğrencilerin 2 . tercihlerinde dizi-sinema oyuncularını $\% 36,1$, müzisyenler $\% 29,5$, sporcular $\% 18$, sunucu-spikerler $\% 5,4$, mankenler $\% 2,5$, sosyal medya fenomenleri \%3,6,çizgi-animasyon karakterleri $\% 2,5$, bilgisayar oyun karakterleri $\% 1,8$, komedyenler $\% 0,5$, moda tasarımcıları $\% 0$ oranında tercih etmişlerdir. Lise öğrencilerin 3. tercihlerinde dizi-sinema oyuncularını $\% 35,2$, müzisyenler $\% 37,2$, sporcular $\% 15,5$, sunucu-spikerler \%3,2, mankenler \%0,5, sosyal medya fenomenleri \%4,2, çizgianimasyon karakterleri \%1,4, bilgisayar oyun karakterleri \%0,8, komedyenler $\% 2$, moda tasarımcıları $\% 0$ oranında tercih etmişlerdir.

Lise öğrencilerinin rol model tercihlerinde medya ünlülerini diğer kurumların rol modellerinden daha yüksek oranlarda tercih etmesi, konuyla ilgili araştırmacıların medya içeriklerinin cazibesinin genç kesimler açısından her geçen gün arttığı, okul ve eğitim kurumların ana aktörlerini ikinci plana ittiği fikrini destekler niteliktedir. Kitle iletişim araçlarının ürettiği eğlenceli, çekici, güzel, güçlü kahramanlar gençlerin özdeşleşip duygusal bağ kurduğu, taklit ettiği, yaşam tarzlarına özenerek model aldığını söylemek mümkündür. $\mathrm{Bu}$ sonuçlardan hareketle anne-baba ve öğretmenlerin gençlerin ilgi duyduğu, model aldığ öncelikli ana aktörler olmadığını göstermektedir. Bu anlamda medyanın yeni nesilleri eğiten önemli bir eğitim kaynağı olarak okulların ve ailelerin önünde olduğu söylenebilir. "Medya 
klasik eğitim araçlarından daha yoğun bir biçimde kullanılmakta, öğrencilerin hayatında önemli rol oynamaktadır. Medya neredeyse çeşitli eğitim kurumlarının işlevlerini üzerine almış görünmektedir" (İnal, 2009, s. 14). Postman da (1994), televizyonun okullardaki eğitim ile boy ölçüşecek hatta onu gölgede bırakacak kadar etkili bir öğretim programı olduğunu ifade etmektedir. Televizyon kültürü ile yoğrulan bir toplumla karşı karşıya olduğumuzu belirten Postman, bu eğitim programının okuma yazma kültürüne saldırdığını ve bireylerin bilişsel alışkanlıklarını kontrol ettiğini belirtir. Giroux da (2007), filmlerdeki modellerin toplumsal değerleri ve rolleri öğretmede aile, okul ya da dini kurumlardan daha güçlü olduğunu ifade etmektedir.

3. Lise öğrencilerinin rol model tercihlerinin sınıf düzeyine göre birbirine yakın olduğu sınıf düzeyinin ciddi bir farklılık yaratmadığı görülmektedir. Medya ünlülerini, öğretmenleri ve arkadaş çevresindeki kişileri öncelikle 9. sınıflar, aile bireylerini öncelikle 11. sınıflar, bilim insanlarını ve tarihi karakterleri ve profesyonel meslek grubundaki kişileri öncelikle 10. sınıflar, dini figürleri öncelikle 12. sinıflar rol model olarak tercih etmektedirler.

4. 2000 TL altı gelir grubundaki lise öğrencileri, diğer gruplara oranla daha çok medya ünlülerini, aile bireylerini ve dini figürleri tercih etmişlerdir. $4000 \mathrm{TL}$ ve üstü gelir grubundaki lise öğrencileri ise diğer gelir gruplarına oranla en az medya ünlülerini ve öğretmenleri tercih etikleri, bu gelir grubundaki öğrencilerin diğerlerine oranla daha çok bilim insanlarını tercih ettikleri tespit edilmiştir. Bu anlamda orta lise öğrencilerinin gelir gruplarına göre rol model tercihleri gelir gruplarına göre değişim göstermiştir. Buradan hareketle alt sosyo ekonomik gelir grubuna sahip olan lise öğrencilerinin medya ünlülerini tercih etme oranlarının, üst sosyo ekonomik gelir grubuna sahip lise öğrencilerine tercih etme oranlarından daha yüksek olduğu söylemek mümkündür.

5. Lise öğrencilerinin rol model tercihleri cinsiyete göre değişim gösterdiği, kadınların daha çok öğretmenleri, aile bireylerini, bilim insanlarını, tarihi karakterleri, edebi karakter ve yazarları erkeklere oranla öncelikle tercih ettikleri; erkeklerin ise, medya ünlüleri, dini figürleri, politikacıları, profesyonel meslek alanlarından kişileri kadınlara oranla öncelikle tercih ettikleri görülmüştür.

6. Medya ünlülerini tercih eden öğrenciler en yüksekten en aza doğru siralandığında; Mersin Mesleki ve Teknik Anadolu Lisesi, Dumlupınar Anadolu İmam Hatip Lisesi, Şevket pozcu Anadolu Lisesi, Fatma Aliye Mesleki ve Teknik Anadolu Lisesi öğrencileri öncelikle rol model olarak tercih etmişlerdir. Mersin Ticaret ve Sanayi Odası Anadolu Lisesi, Mahmut Aslan Anadolu Lisesi ve İçel Anadolu lisesi ise diğer okullara göre medya ünlülerini daha düşük oranlarda tercih yaptıkları görülüştür. Öğretmenleri en çok Şevket pozcu Anadolu Lisesi öğrencileri ve Mersin Mesleki ve Teknik Anadolu Lisesi öğrencileri tercih yapmışlardır. Tarihi karakterleri en çok İçel Anadolu Lisesi öğrencileri ve Mersin Ticaret ve Sanayi Odası Anadolu Lisesi öğrencileri ile Mahmut Aslan Anadolu Lisesi öğrencileri tercih yapmışlardır. Edebi karakter ve yazarları en çok Mersin Ticaret ve Sanayi Odası Anadolu Lisesi öğrencileri tercih etmiş̧lerdir. İçel Anadolu ve Mahmut Aslan Anadolu Lisesi öğrencilerinin diğer liselere göre daha az medya ünlülerini tercih etmesi, ya da daha çok bilim insanlarını rol model olarak tercih etmeleri, bu liselerde eğitim gören öğrencilerin liselere geçiş sınavında daha yüksek puanlarla bu okullara girmiş olmaları da dikkat çekici bir noktadır.

7. Lise öğrencilerin örnek aldıkları rol modellerin özellikleri hakkındaki görüşlerine baktığımızda; lise öğrencilerinin rol model olarak tercih ettiği kişilerin büyük oranlarda davranışlarını örnek aldıklarını, fikir ve düşüncelerine önem verdiklerini, giyim tarzlarını kendime örnek aldıkları konusunda görüş beyan etmektedir. Aynı şekilde rol model olarak benimsedikleri kişiler hakkında sosyal medyada araştırma yaptıklarını, sosyal medyada bilgi, fotoğraf, video vb. paylaşım yaptığını, bu kişilerin kendi bilimsel entelektüel kültürlerini artırdığını, kullandığı ürünleri kullanmak istediğini, kişiliklerini örnek benimsediklerini, sözlerine değer verdiğini konusunda görüş belirtmişlerdir. Buradan hareketle bir ülkenin geleceğinde söz sahibi olacak genç nesillerin öncelikle rol model tercihlerinde medya ünlülerini benimsiyor olması, gençlerin medya ünlüleri gibi davranış örnekleri sergilemeleri, ünlülerin fikir ve düşüncelerine sahip olmaları, ünlüler gibi yaşam tarzı benimsemelerini beklemek yanlış 
olmayacaktır. Bu anlamda medya ünlülerinin temsil ettiği olumlu ve olumsuz değerler önem kazanmakta, ünlülerin temsil ettiği kişilik ve davranış özelliklerinin gelecekte o ülkenin kültürel yapısının temelini oluşturacağını söylemek mümkündür.

8. Lise öğrencilerin rol modellerini tercih etme nedenlerine baktı̆̆ımızda; Lise öğrencilerin rol modellerini tercih ederken $\% 90$ ak1llı olmas1, \%88 bilgili olmas1, \%85 Yardımsever, özgür ve yaratıcı olması, \% 84 cesur olmas1, \% 83 adil olmas1, \%83 sorun çözebilmesi, \%81 güvenilir olması, \%79 vatansever olması, \% 75 hırslı olması, \%72 kurtarıc1 olması, \%70 mesleği, nedenlerine sirasıyla öncelik verdikleri görülmüştür. Daha sonra sırasıyla $\% 63$ esprili olmas1, \%62 karizmatik olması, \%60 savaşçı olması, \%56 giyim tarzı, \%53 Fiziksel özelliği ve duygusal olması, $\% 38$ şöhretli olması, $\% 33$ zengin olması nedenlerine sırasılya tercih ettiklerini belirtmişlerdir. Buradan hareketle lise öğrencileri tercih ettikleri rol modellerinin olumlu olarak düşündükleri özelliklerinden dolayı tercih ettiklerini ifade etmektedirler.

Lise öğrencilerin rol modellerini tercihlerinin yarısından fazlasını medya ünlülerinin oluşturduğu sonucundan hareketle; medya tarafindan yaratılan ve üretilen ünlülerin olumlu özelikler ile temsil edilmesi (cesaretli, zeki, güzel yakışıklı olarak sunulması, eğlenceli, esprili komik olarak temsil edilmeleri, kitlenin duygularına hitap edecek şekilde kurgulanması, genç bireylerin kendi başına çözümleyemediği sorulara cevaplar veriyor olabilmeleri), bu kesimler tarafından benimsenmesinde önemli rol oynadığını söylemek mümkündür. Öte taraftan medya ünlülerinin temsil edilen olumlu özelliklerinin yanında olumsuz özellikler ile temsil edildikleri (şiddet, tüketim, cinsiyetçilik vb.) boyutlarının da var olduğunu düşünürsek genç kesimlerin farkında olarak ya da olmayarak bu özellikleri de aldıklarını söyleyebiliriz.

Toplumlar sahip oldukları kültürü, bilgiyi, değerleri belirli rol modeller üzerinden gelecek kuşaklara aktarırlar. Bu anlamda öğrencilerin tercih ettikleri veya onlara sunulan rol modeller onların kişiliğine, karakterine dünyayı görme şeklini, benimsedikleri davranışları, değerler üzerinde etkisi olabilmektedir. Rol modeller üzerinden öğrenilen bilgi ve beceriler sayesinde tutum ve davranış değişikliği meydana gelebilmektedir. Öğrencilerin rol model olarak benimsediği kişilerin niteliği bir ülkenin ekonomik ve kültürel gelişimi ve geleceği açısından önemli hale gelmektedir. Bir ülke ekonomik olarak zenginleşmek, kalkınmak, kültürel olarak gelişmek istiyorsa bilim insanı, araştırmacı, düşünce ve bilgi niteliği bakımından gelişmiş rol modelleri yaygınlaştırması, teşvik etmesi bir zorunluluk haline gelmektedir. Medyanın sunduğu rol modelleri içerisinde bilim insanı ve araştırmacı özellikteki kişilerin olmaması, dikkat çekicidir.

Medya kurumundaki rol modeller amaç ve özellikler açısından okul ve aileden farklılık göstermektedir. Medya kurumundaki rol modeller ise medya tarafından popüler yapılan, tanıtılan, dizi oyuncuları, sinema aktörleri, çizgi film kahramanları, müzisyenler, spikerler, modacılar, mankenler, futbolcular vb. kişileri kapsamaktadır. Medyanın sunduğu rol modeller önemli ölçüde bireylerin tüketime teşvik edilmesi, tüketici yaşam tarzının sunması, satın alma davranışlarını öğretilmesi yönünde olmaktadır. Medyanın çocuklara ve gençlere sunduğu rol modellerin diğer bir özelliği, bu modellerin endüstriyel yapılar tarafından ekonomik ve kültürel amaçlar doğrultusunda tasarlanması ve pazarlanmasıdır. Günümüz küresel kapitalizm koşullarında televizyon program yapımların üretimi yapılan rol modeller çokuluslu şirketler tarafından gerçekleştirilmektedir. Bu modeller, bireylerde ekonomik, kültürel ve politik amaçlar doğrultusunda bireylerde davranış oluşturma ve yönlendirmede kullanılabilmekte, tüketim kültürünü, tüketici yaşam tarzı ve modayı öğretmektedir. Aile ve okul çocuklara yaşayan veya yaşamış gerçek kişileri rol model olarak sunarken; medya ise çoğunlukla kurgusal ve hayali, gerçek dış1, olağanüstü özelliklerle donatılmış karakterleri rol model olarak sunmaktadır.

Medya kuruluşları belirli ekonomik ve kültürel hedefler çerçevesinde genç kesimlere popüler kişiler üzerinden, onların sosyal olayları, olguları, nesneleri, kişileri, hayatı nasıl algılayacakları noktasında eğitmekte, onların önemli bilgi ve sosyalleşme kaynağını oluşturmaktadır. Medyada sunulan rol modellere yönelik önemli bir eleştiri konusu, bu modellerin çoğunlukla şiddet eğilimli, şiddet uygulayan karakterler olması ve bunu izleyen tüketen bireyler tarafindan bu şiddetin benimsenmesi ve uygulanmasina neden olduğudur. Yapılan pek çok araştırma medyada dizi ve sinema filmlerinde karakterlerin şiddet kullanması 
şiddet eğilimli bireyler yetiștirmesine zemin hazırladığını ve tüketenlerin şiddet uygulama eğilimlerinin artı̆̆ını desteklemektedir. Şentürk ve Turğut'a (2001, s. 65) göre, çocukların izledikleri saldırgan davranışları sonradan taklit ettikleri, üstelik ortaya koyduklarından daha fazlasını öğrendikleri gözlemlenmiştir. Genç nesillerin medyada yoğun şiddet görüntü ve içeriklerine maruz kalması sosyal alanda ailede, okulda, sokakta şiddet olaylarına, korku kültürüne zemin oluşturabilmekte, bireysel olarak şiddet eğilimli kişilikler yaygınlaşabilmekte, toplumsal dayanışmayı ve güveni azalabilmektedir (Bourdieu, 1997; Esslin, 2001; Ramonet, 2000). Yağbasan ve Kurtbaş (2015, s. 27), televizyonun model oluşturarak topluma şiddettin pompalanmasına ve herkesin tüketimin nesnesine dönüştürülmesine aracılık ettiğini ifade eder. Ergeç ve Doğan (2016), medyadaki şiddet sahnelerine maruz kalmanın, çocuklarda saldırgan davranışları arttırdığını belirtmektedirler. Erdoğan, Ekși, Tektaş (2012) ise, gençlerin dizilerde şiddeti öğrendiğini ve şiddete karşı duyarsızlaştığını ifade etmektedirler. Sanders (1999, s.138), çocukların televizyonda gördüğü şiddeti uygulama, taklit etme, model alma yoluyla içselleştirdiklerini belirtmektedir. Ertürk ve Gül (2006), televizyon izleyen çocuklarda, fiziksel saldırganlığın artması, şiddete başvurma, şiddete karşı duyarsız olma, okuma zevkinde azalma, ders çalışmaya karşı isteksizlik, dikkatini yoğunlaştıramama, kendini ifade edememe, kendini izlediği kahramanların yerine koyarak gerçeklerden uzaklaşma, hayal gücü ve yaratıcılığın kısıtlanması, sosyal ilişkilerin zayıflaması, gibi olumsuz etkiler saptanmıştır.

Medya ünlüleri aracılığıyla bireylerin tüketim alışkanlığı ve ürünlere sahip olma isteği değiş̧ebilmekte, markalara yönelik algıları değiştirebilmekte, bireyin tüketim beklentileri artabilmekte, ürünlere yönelik bağımlılığı ve tutkusunu artabilmektedir. Medya içeriklerinin önemli bir bölümü bireyleri tüketim konusunda eğiterek, yönlendirerek, onların sürekli ve daha çok satın almaları, iyi bir tüketici olmaları konusundadır. Tüketicilerin moda, giyim, gıda, elektronik ürün, kozmetik, oyuncak gibi pek çok ürünün satın alınmasında, alışveriş tutkusu ve bağımlılığının gelişmesinde katkı sunar.

Medyan içerikleri rol modeller üzerinden bireyleri hareketsiz bir yaşama alıştırdığı, beslenme alışkanlıklarını, fiziksel ve ruhsal sağlıklarını olumsuz yönde etkilediği, ideolojik olarak bireyci, bencil, kimlikler üreterek bireylere çıkarcı fikirler aşıladığ 1 , zihinsel becerilerini körelttiği, onları cahilleştirdiği noktasında eleştirilmektedir (Avc1, 1999; Kellner, 2010; Postman, 1994; Ramonet, 2000; Wernick, 1996). Sanders (1999), kitle iletişim araçlarının içeriklerinin bireylerin aklını kullanma, muhakeme yapma, etkili iletişim kurma gibi becerilerin geliştirilmesinde olumsuz anlamda etki ettiğini belirtmektedir. Sanders, televizyonun çocukların düşünmesini engellediği gibi, onların dil gelişimi üzerinde de olumsuz anlamda etkili olduğunu belirtmektedir.

Medya belirli kişileri ticari amaçlar doğrultusunda üreterek, tasarlayarak ve pazarlayarak reklamlarda ürünlerin satın alınmasında kullanabilmekte, dolayısıyla insanlarda satın alma eğilimini kışkırtabilmekte ve borçlanmasına sebebiyet verebilmektedir. Medya yarattığ 1 ünlü kişilerin güvenilir, inanılır ve beğenilir kahramanlara dönüştürülmesinde bir takım reklam ve pazarlama teknikleri kullanabilmektedir. Medya ünlüleri, program türlerinde firmaların ürünlerini kullanması bireylerin o ürünlere yönelik bakış açılarının değişebilmesine neden olabilmekte, elektronik, gıda, giyim, ev ürünleri, otomotiv, bankacilık, mal ve hizmet sektörlerinde kullanılması ve onlar üzerinden büyük miktarlarda karların elde edilmesine vesile olabilmektedir. Bu anlamda medya ünlülerinin, medya kurumunun öncelikli ticari amaçları için kullandığı bir araç konumunda olduğunu söylemek mümkündür

Okulun önemli rol modelleri arasında olan öğretmenler, ülkenin kalkınmasında, zenginleşmesinde, bireylerin sosyalleşmesinde, yaşama hazırlanmasında, toplumsal değerlerin aktarılmasında, bireyin sahip olduğu düşünce sistemi ve dünyayı görme şeklinin belirlenmesinde önemli rol oynar. Bu çalışma göstermektedir ki, lise öğrencilerin tercih ettikleri rol modellerinde bilim insanları, politikacı, şair, yazar, ressam, filozof, psikolog, ekonomist, sosyolog gibi mesleklerdeki kişilerin oranı çok düşük düzeylerdedir. Bir ülkenin ekonomik olarak kalkınması ve zenginleşmesi, kültürel olarak gelişmesi, toplumsal huzurun ve güvenin sağlanması nitelik ve beceri açısından profesyonel mesleklerdeki rol modellerin sunulması, çekici hale getirilmesi ve yaygınlaştırılması bir zorunluluk haline gelmektedir. Aynı zamanda 
genç nesillerin medya ünlülerini önemli bir oranda tercih etmesi toplumun gelecekte sosyal, ekonomik ve kültürel olarak alacağı şekil açısından bize birtakım olumsuz ipuçları verebilmektedir.

\section{Kaynaklar}

Aydın, B. (2005). Ergen psikolojisi. İstanbul: Atlas Yayın Dağıtım.

Aydın, B., Akbağ, M., Tuzcuoğlu, S., Yaycı, L. ve Ağır, M. (2005). Gelişim ve öğrenme. B. Aydın (Yay. Haz.). İstanbul: Nobel Yayıncilık.

Bandura, A. (1986). Social foundations of thought and action: A social cognitive theory, Prentice-Hall. Upper Saddle River, NJ.

Bandura, A. (1969). Social learning theory of idendificatory processes. D.A. Goslin (Yay. Haz.) Handbook of Socialization Theory and Research, içinde (ss. 213-262). Rand McNally \&Company, Chicago.

Bandura, A. (1977). Social learning theory. NJ: Prentice Hall.

Bocock, R. (1997). Tüketim. İ. Kutluk (Çev.). Ankara: Dost Yayınları.

Chiou, J. S., Huang, C. Y. ve Chuang M. C. (2005). Antecedents of taiwanese adolescents purchase intention toward the merchandise of a celebrity: The moderating effect of celebrity adoration. The Journal of Social Psychology, 145(3), 317-332.

Demir, E. ve Köse, M. (2014). Öğretmenlerin rol modelliği hakkında öğrenci görüşleri. Uluslararast Sosyal ve Ekonomik Bilimler Dergisi, 4(1), 8-18.

Demirbaş, M. ve Yağbasan, R. (2005). Sosyal öğrenme teorisine dayalı öğretim etkinliklerinin, öğrencilerin bilimsel tutumlarının kalıcılığına olan etkisinin incelenmesi. Uludă̆ Üniversitesi Eğitim Fakültesi Dergisi, 18(2), 363-382.

Erdoğan, Y., Ekşi, H. ve Tektaş, A. (2012). Medya ve şiddet: Mafya dizileri üzerine karma bir araştırma. Değerler Ĕ̈itimi Dergisi, 23, 83-116.

Ergeç, N. E. ve Doğan, M. E. (2016). Medyada şiddet; televizyon çizgi diziler üzerine bir inceleme. Ç. Ü. Sosyal Bilimler Enstitüsü Dergisi, 25(1), 43-58.

Erjem, Y. ve Çağlayandereli, M. (2006). Televizyon ve gençlik: yerli dizilerin gençlerin model alma davranışı üzerindeki etkisi. C. Ü. Sosyal Bilimler Dergisi, 30(1), 15-30.

Ertürk, Y. D. ve Gül, A. A. (2006). Çocuğunuzu televizyona teslim etmeyin. Ankara: Nobel Yayın Dağıtım.

Giroux, H. A. (2007). Eleştirel pedagoji ve neoliberalizm. İstanbul: Kalkedon Yayınları.

Hürriyet. (2015). Ergenler neden ünlülere hayran oluyorlar? Erişim adresi: www.hurriyetaile.com/ergenlik/psikolojik-gelisim/ergenler-neden-unlulere-hayranolurlar_18032.html

İnal, K. (2009). Medya okuryazarlı̆̆ el kitabı. Ankara: Ütopya Yayıncılık

Karaboğa, T. (2016). Dizi izleyicilerinin televizyon dizilerinde sunulan tüketim unsurlarina yönelik eğilimleri. Akademik Sosyal Araştırmalar Dergisi, 4(27), 182-208.

Kellner, D. (2010). Medya gösterisi, Z. Paşalı (Çev.). İstanbul: Açılım kitap.

Kelman, H. C. (1961). Processes of Opinion Change. Public Opinion Quarterly, 25, 57-78.

Kılıç, M., Kaya, A., Yıldırım, N. ve Genç, G. (2004). Eğitimci gözüyle öğretmen ve öğrenci. XIII. Ulusal Eğitim Bilimleri Kurultayl. 6-9 Temmuz 2004. İnönü Üniversitesi, Eğitim Fakültesi, Malatya.

Kıyan, Z. (2016). Metalaştırma ve direnç. Kapitalizmde kültürün ikili üretim yapısı. İstanbul: Nota Bene Yayınları.

Kula, D. N. (2007). Elazığ' da Kurtlar Vadisi dizisinin alımlanması. Afyon Kocatepe Üniversitesi Sosyal Bilimler Dergisi, 2, 251-266.

Manz, C. C. ve Sims, H. P. (1981). Vicarious learning: The influence of modeling on organizational behaviour. The Academy of Management Review, 6(1), 105-113.

Martin, C. A. ve Bush, A. J. (2000). Do role models influence teenagers' purchase intentions and behavior? Journal of Consumer Marketing, 17(5), 441-454.

Oruç, C., Tecim, E. ve Özyürek, H. (2011). Okul öncesi dönem çocuğunun kişilik gelişiminde rol modellik ve çizgi filmler. Ekev Akademi Dergisi, 15(48), 303-319. 
Öcal, A., Polat, R. ve Arı, G. (2011). Sosyal bilgiler ve T.C. Atatürk ilkeleri ve inkılap tarihi ders kitaplarındaki karakterlere ilişkin öğrenci görüşleri. 2. International Conference on New Trends in Education and Their Implications içinde (ss. 27-29).

Özel, E. ve Zelyurt, H. (2016). Anne baba eğitiminin aile çocuk ilişkilerine etkisi. Sosyal Politika Çalışmaları Dergisi,(36), 9-34 .

Polat, R. (2012). 12-14 Yaş grubu ögrencilerin kahraman algılarının incelenmesi: Sincan ilçesi örneği (Yayımlanmamış yüksek lisan tezi). Aksaray üniversitesi, Aksaray.

Postman, N. (1994). Televizyon: Öldüren eğlence (gösteri çağında kamusal söylem). O. Akınhay (Çev.). İstanbul: Ayrıntı Yayınları.

Ramonet, I. (2000). Medyanın zorbalığı. A. Derman (Çev.), İstanbul: Om yayıncılık.

Run, E. C., Butt, M. ve Nee C. Y. (2010). The influence of role models on young adults purchase. Jurnal Kemanusiaan,(15), 70-81.

Sanders, B. (1999). Öküzün A'sı: Elektronik çağda yazılı kültürün çöküşü ve şiddetin yükselişi. Ş. Tahir (Çev.), İstanbul: Ayrıntı Yayınları.

Sarı, E. (2005). Öğretmen adaylarının değer tercihleri: Giresun eğitim fakültesi örneği. Değerler Ĕ̈itimi Dergisi, 3(10), 73-88.

Seferoğlu, S. S. (2001). Sınıf öğretmenlerinin kendi mesleki gelişimleriyle ilgili görüşleri, beklentileri ve önerileri. Milli Ĕ̈itim Dergisi, 149, 12-18.

Senemoğlu, N. (2007). Gelişim, öğrenme ve ögretim: kuramdan uygulamaya. Ankara: Gönül Yayınevi.

Şişman, M. (2006) Ĕgitim bilimine giriş, Ankara: Pegem A Yayıncılık.

Tekarslan, E., Kılınç, T., Şencan, H. ve Baysal, A.C. (2000). Davranışın sosyal psikolojisi. İstanbul: İ.Ü. İşletme Fakültesi Yayınları.

Türkmen Barutçu, M. ve Sarıkaya, N. (2016). 11-14 Yaş arası ilk dönem çocuk ergen tüketicilerin alıșveriș davranışlarında ünlü kiși etkisi. Pazarlama ve Pazarlama Araştırmaları Dergisi, (17), 43-64.

Türkmen, M. (2014). İlk dönem çocuk ergenlerin (11-14 yaş arası) alışveriş davranışlarında rol model etkisinin incelenmesi (Yayımlanmamış yüksek lisan tezi). Sakarya üniversitesi, Sakarya.

Ünver, T. (2002). Bir popüler kültür ürünü: çizgi film pokemon (Yayılanmamış yüksek lisans tezi). Gazi Üniversitesi, Ankara.

Wernick, A. (1996). Promosyon kültürü, reklam, ideoloji ve sembolik anlatım. O. Akınhay (Çev.). Ankara: Bilim Sanat Yayınları.

Yağbasan, M. ve Kurtbaş, İ. (2015). Şiddet ve tüketim kıskacında çocukluk: Televizyon üzerine ampirik bir çalışma. Ardahan Üniversitesi İktisadi ve İdari Bilimler Fakültesi Dergisi, (2), 15-31.

Yener, F. (2011). Sorunlu ögrrenci davranışlarının çözümünde yönetici ve öğretmenlerin rol model davranışlarının önemi (Yayımlanmamış yüksek lisans tezi). Kocaeli Üniversitesi Sosyal Bilimler Enstitüsü, Kocaeli.

Yıldız, S. A. (2007). Sosyal öğrenme teorisi açısından medya ve çocuk suçluluğu. 4. Uluslararası Çocuk ve İletişim Kongresi, içinde (ss. 117-126). İstanbul: İstanbul Üniversitesi İletişim Fakültesi.

Yurdakul, S. ve G. Üstün (2009). 13-18 Yaş ergenlerin giysi seçiminde ebeveynlerin etkisi. Elektronik Sosyal Bilimler Dergisi, 8(28), 273-285.

\section{Extended Abstract \\ Introduction}

Through certain role models social institutions try to realize the culture, information and values that they want to convey in accordance with specific goals and objectives. The role models offered by the students or presented to them can affect their personality, the way they see the world, their behavior, and their values. Attitudes and behaviors can be changed through knowledge and skills learned through role models. In this sense, the quality of role models that students take as a model is important for the economic and cultural development and future of a 
country. Nowadays, people in different institutions can be a source of a role model for the students studying in secondary education. Family, school and media are among the most important sources of these institutions. An education process is carried out both in family and school in order to train individuals' beneficial individuals and citizens for their families and the country. On the other hand, media institutions educate young people through the role models and affect them in terms of how they perceive social events, phenomena, and people, in the context of specific economic and cultural objectives. This research aims to determine to what extent high school students choose which role models from different institutions and areas.

\section{Method}

This research aimed to determine high school students' role model preferences. It is a descriptive study and the data were collected by the help of High School Students' Role Model Preferences Questionnaire. The data of this research were gathered from 700 high school students registered inŞevket Pozcu Anatolian High School, İçel Anatolian High School, Mersin Ticaret ve Sanayi Odas1 Anatolian High School, Mahmut Arslan Anatolian High School, Dumlupınar Anatolian İmam Hatip High School, Fatma Aliye Vocational and Technical Anatolian High School and Mersin Vocational and Technical High School. The opinions of the secondary school students who participated in the research about who they preferred as a role model were examined with frequency and percentage descriptive statistical techniques by following the research questions.

\section{Findings}

Based on the analyses on the role model preferences of high school students following findings have been achieved:

1. The role model priorities of high school students' role model preferences were as follows: $51 \%$ in the media celebrities, $10 \%$ in the historical characters, $9 \%$ in the family members, $6 \%$ in the professional occupation groups, $5 \%$ in the teachers, $5 \%$ in the literary characters and the writers, $4 \%$ in the scientists, $1,5 \%$ in the religious figures, respectively. 1.3 , friends around $0.5 \%$.

2. The distribution of high school students' role model preferences according to areas of media celebrities was as follows: Series-cinema players 36.5\%, musicians 32\%, athletes $16.5 \%$, server-headers $4.2 \%$, mannequins $1.6 \%$, social media phenomena $3.8 \%$, animated characters $1.7 \%$, computer game characters $1.3 \%$, comedians $1.9 \%$, and fashion designers $0.6 \%$. In the field of media, the most important role model preferences of high school students are seriescinema actors, musicians and athletes. It can be said that high school students prefer media celebrities as a role model at a high rate. It was determined that the ratio of preferring family members, historical characters, people in professional occupation groups, scientists, teachers, literary characters, and authors as role models was low. It has been observed that the rate of secondary school students' preference of politicians, religious figures, and friends as role models is quite low.

3. It is seen that high school students' role model preferences do not show a serious separation according to the grade level that means the role model preference ratios are close to each other according to the grade level.

4. High school students in the under 2.000 TL income group preferred media celebrities, family members and religious figures more than other groups of students. High school students in the income group of $4.000 \mathrm{TL}$ and above were leastly preferred media celebrities and teachers as their role models compared to other income groups. In addition, it was determined that the rate of preference of scientists as role model in this income group was higher than the others. In this sense, it can be said that the role model preferences of high school students according to income groups have changed.

5. The role model preferences of high school students have changed according to gender. While the female students preferred teachers, family members, scientists, historical characters, literary characters and writers as role models more than male students male 
students preferred media celebrities, religious figures, politicians, and people from professional occupations as role models more than female students.

6. When students who preferred media celebrities as role models are ranked from highest to lowest according to school they attend the following school ranking have been achieved; Mersin Vocational and Technical Anatolian High School, Dumlupınar Anatolian İmam Hatip High School, Şevket Pozcu Anatolian High School, Fatma Aliye Vocational and Technical Anatolian High School students preferred primarily as a role model. Mersin Ticaret ve Sanayi Odası Anatolian High School, Mahmut Arslan Anatolian High School and İçel Anatolian High School.

7. When we look at students' views on the characteristics of their role models, it was observed that high school students take their role models' behaviors and on the way they dressed as example and gave a great importance to their ideas and thoughts. In the same way, students stated that they search on social media about the people they adopt as role models and share information, photos, videos etc. on social media and also they think that role models increase their scientific intellectual culture. In addition, they think they want to use the products the role models use and they adopt their personality and appreciate their words.

8. When we look at the views of high school students on the reasons for preferring role models; it is seen that students primarily consider role models' characteristics such as being smart, knowledgeable, helpful, free and creative, courageous, fair, problem-solving, reliable, patriotic, ambitious, rescuer, and profession. Then they stated that they consider role models' characteristics such as being humorous, charismatic, warrior, clothing style, physical character and emotionality, reputation and richness, respectively.

\section{Discussion}

The attractiveness of media contents for young people is increasing day by day and the main actors such as schools and educational institutions seem to be pushed to the second plan. Students are getting identified with the fun, attractive, beautiful, powerful heroes of the mass media and they are creating emotional ties, imitating them, and modeling their lifestyles. It is seen that parents and teachers are not gradually becoming the main actors. In this sense, the media are ahead of schools and families as an important educational resource for educating new generations.

Through certain role models social institutions try to realize the culture, information and values that they want to convey in accordance with specific goals and objectives. The role models offered by the students or presented to them can affect their personality, the way they see the world, their behavior, and their values. Attitudes and behaviors can be changed through knowledge and skills learned through role models.

Teachers, who are among the important role models of the school, play an important role in the development of the country, in the socialization of the individuals, in the preparation of life, in the transfer of the social values, in determining the individual's own system of thought and the way in which they see the world. Like teachers school books also present various role models such as historical characters, politicians, writers, painters, philosophers, psychologists, economists, sociologists and so on. This study shows that among the role models that high school students prefer, scientists, politicians, poets, writers, painters, philosophers, psychologists, economists, sociologists, etc. are at very low levels. However, it is a necessity to offer role models in professions in terms of qualifications and skills in order to provide economic development and prosperity, cultural development, social peace and trust.

The role models presented in media differ from school and family in terms of purpose and characteristics. The role models that are popularized and introduced by media include TV series actors, actors of cinema, cartoon heroes, musicians, anchors, fashion designers, mannequins, footballers and so on. The role models offered by the media could aim to encourage individuals to consumption, to present consumer lifestyle and to teach purchasing behaviors. Another feature of the role models offered by media to children and young people is that these models are designed and marketed by industrial structures in line with economic and 
cultural objectives. The media can use a number of advertising and marketing techniques to transform famous people into reliable, credible and admirable heroes.

Another critical critique of the role models presented in the media is that these models are mostly violent characters, and that the subsequent consuming individuals have led to the adoption and implementation of this violence. Many studies support the idea that the violence of the characters in the series and cinema films has prepared the ground for the education of the individuals who are prone to violence and that the consumers tend to increase their tendency to use violence. 